Supporting Information (SI)

For

\title{
Molecular Understanding of Humic Acid-Limited Phosphate Precipitation and Transformation
}

\footnotetext{
Xinfei Ge, ${ }^{\dagger}$ Lijun Wang, ${ }^{* \dagger}$ Wenjun Zhang,,${ }^{*}$ and Christine V. Putnis ${ }^{\star, \S}$

${ }^{\dagger}$ College of Resources and Environment, Huazhong Agricultural University, Wuhan 430070,

China

Institut für Mineralogie, University of Münster, 48149 Münster, Germany

${ }^{\S}$ Department of Chemistry, Curtin University, Perth 6845, Australia
}

Number of pages: 25

Number of figures: 29

Number of tables: 4 


\section{SI Methods}

Supersaturated Solution Preparations. Supersaturated solutions of dicalcium phosphate dihydrate $\left(\mathrm{DCPD}, \mathrm{CaHPO}_{4} \cdot 2 \mathrm{H}_{2} \mathrm{O}, \sigma_{\mathrm{DCPD}}=0.168-0.900\right.$, ionic strength $(I S)$ $\left.=0.15 \mathrm{M}, \mathrm{pH}=5.6,25^{\circ} \mathrm{C}\right)$ or hydroxyapatite $\left(\mathrm{HAP}, \mathrm{Ca}_{10}\left(\mathrm{PO}_{4}\right)_{6}(\mathrm{OH})_{2}, \sigma_{\mathrm{HAP}}=\right.$ 13.6-32.9, IS $=0.15 \mathrm{M}, \mathrm{pH}=8.0,25^{\circ} \mathrm{C}$ ) were prepared by slowly mixing of stock solutions of $\mathrm{CaCl}_{2}(0.04 \mathrm{M}), \mathrm{KH}_{2} \mathrm{PO}_{4}(0.04 \mathrm{M})$ and $\mathrm{NaCl}(1 \mathrm{M})$, and the solution $\mathrm{pH}$ was adjusted by $0.1 \mathrm{M} \mathrm{KOH}$ (see details in Table S4). The relative supersaturation with respect to DCPD or HAP is defined as $\sigma=\frac{\text { IAP }}{k_{\mathrm{sp}}}-1$, where the IAP is the ionic activity product, and $K_{\mathrm{SP}}$ is the solubility product $\left(-\log \left(K_{\mathrm{SP}}\right)=6.59\right.$ for $\mathrm{DCPD}, 25^{\circ} \mathrm{C}$; $\left(-\log \left(K_{\mathrm{SP}}\right)=116.8\right.$ for HAP, $\left.25^{\circ} \mathrm{C}\right) .{ }^{1}$ The above $\sigma$ values for ACP nucleation were chosen in order to obtain enough formed particles on mica during $1 \mathrm{~h}$. Additionally, humic acid (HA) at concentrations ranging from 0.01 to $0.5 \mathrm{mg} / \mathrm{L}$ was immediately added to supersaturated solutions prior to each experiment. All the reagents were purchased from Sigma Aldrich (St. Louis, MO) and solutions were prepared with ultrapure water $(18.2 \mathrm{M} \Omega \cdot \mathrm{cm}$ resistance, Milli-Q, Billerica, MA).

Bulk DCPD/HAP Nucleation. Supersaturated DCPD $\left(\sigma_{\mathrm{DCPD}}=0.799, I S=0.15 \mathrm{M}\right.$, $\left.\mathrm{pH} 5.6,25^{\circ} \mathrm{C}\right)$ or HAP $\left(\sigma_{\mathrm{HAP}}=32.3, I S=0.15 \mathrm{M}, \mathrm{pH} 8.0,25^{\circ} \mathrm{C}\right)$ solutions were used to perform bulk nucleation experiments. The reaction solutions of supersaturated DCPD or HAP in the absence and presence of 0.01 or $0.5 \mathrm{mg} / \mathrm{L} \mathrm{HA}$ were made up to the final volume of $40 \mathrm{~mL}$ in a double-walled Pyrex vessel using a constant magnetic stirring. During all nucleation experiments, nitrogen $\left(\mathrm{N}_{2}\right)$ gas was continuously pumped into the supersaturated solution to remove carbon dioxide. The energy-saving 
intelligent thermostat (SDC-6, SCIENTZ) was used to maintain a constant temperature of $25{ }^{\circ} \mathrm{C}$. The $\mathrm{pH}$ change was monitored using a glass $\mathrm{pH}$ electrode incorporating a reference electrode. All data of induction times were presented as mean values \pm standard deviation of three independent sets.

Ion Selective Electrode Experiment. A computer-controlled titration system (Titrando 888, Metrohm, Switzerland) equipped with a calcium ion selective electrode (Ca-ISE) was used to detect the concentration change of $\mathrm{Ca}^{2+}$ in supersaturated DCPD or HAP solutions during nucleation in the absence and presence of $0.01-10 \mathrm{mg} / \mathrm{L} \mathrm{HA}$, respectively. The potential of the Ca-HA solution with different concentrations of calcium ions $(12.3-13.5 \mathrm{mM}, I S=0.15 \mathrm{M}, \mathrm{pH} 5.6 ; 1.86-1.92 \mathrm{mM}, I S=0.15 \mathrm{M}, \mathrm{pH}$ 8.0) was measured in an $80 \mathrm{~mL}$ double-walled Pyrex vessel at a constant magnetic stirring. During the whole experiments, nitrogen gas $\left(\mathrm{N}_{2}\right)$ was continuously introduced to remove carbon dioxide from the solution, and the temperature was maintained at $25{ }^{\circ} \mathrm{C}$ with energy-saving intelligent thermostat (SDC-6, SCIENTZ). The potential $\mathrm{U}\left(\mathrm{Ca}^{2+}\right)$ was recorded by timo 2.2 software and then connected to the concentration $\mathrm{c}\left(\mathrm{Ca}^{2+}\right)$ by the calcium electrode correction equation. The obtained data of the concentration $\mathrm{c}\left(\mathrm{Ca}^{2+}\right)$ were shown as mean values \pm standard deviation of three independent sets.

\section{In Situ AFM Experiments}

a. AFM Imaging of ACP Nucleation on Mica. The in situ experiments of $\mathrm{Ca}-\mathrm{P}$ nucleation were observed on the (001) surface of freshly-cleaved muscovite mica using an AFM (NanoScope Multimode 8, Bruker) equipped with a liquid cell. AFM 
images were collected using commercially available $\mathrm{Si}_{3} \mathrm{~N}_{4}$ probes with silicon as tip and silicon nitride as the cantilever (Bruker ScanAsyst fluid ${ }^{+}$including $\mathrm{k}=0.7 \mathrm{~N} / \mathrm{m}$ and tip radius $<12 \mathrm{~nm}$ ) in the ScanAsyst mode at a scan rate of $2.0 \mathrm{~Hz}$ for $2 \times 2 \mu \mathrm{m}^{2}$ scan area at $25{ }^{\circ} \mathrm{C}$. The supersaturated solutions were well mixed in the beaker and a high-precision syringe pump (Razel Scientific Instruments model R100-E) was used to flow solutions through the fluid cell at a constant rate of $10 \mathrm{~mL} / \mathrm{h}$ to ensure steady-state kinetic nucleation conditions rather than diffusion-controlled nucleation conditions during the nucleation experiments. Moreover, the roughness of mica was measured prior to each AFM measurements and was consistently averaged at less than $0.5 \mathrm{~nm}$, and the determination of nucleation rates in different supersaturated solutions was made from the number of nuclei with a height of about $2 \mathrm{~nm}$ after reaction of 60 min in the absence and presence of various concentrations of HA ranging from 0.01 to $0.5 \mathrm{mg} / \mathrm{L}$. For statistical the number of nuclei, a newly-cleaved mica surface obtained at zero time is atomically smooth for AFM observations during nucleation experiments. when the prepared supersaturated solution was pumped into fluid cell, the first AFM image obtained needed 3-5 minutes to complete the scan, during which time several particles were already formed. Therefore, the statistics during that time, and presented in Figure 1, exhibited several nuclei just after zero time.

b. AFM Imaging of DCPD Surface Growth. DCPD crystals were synthesized by a gel method ${ }^{2}$ and were used for in situ AFM surface growth experiments. Images were obtained in contact mode at a scan rate of $2.0 \mathrm{~Hz}$ using $\mathrm{Si}_{3} \mathrm{~N}_{4}$ probes with silicon nitride as tip and cantilever ((Bruker DNP-S10, spring constants of 0.12 to $0.35 \mathrm{~N} / \mathrm{m}$ ). 
A supersaturated solution $\left(\sigma_{\mathrm{DCPD}}=0.581, I S=0.15 \mathrm{M}, \mathrm{pH} 5.6,25^{\circ} \mathrm{C}\right)$ with $0.01 \mathrm{mg} / \mathrm{L}$ HA was pumped into the liquid cell at a constant rate $(10 \mathrm{~mL} / \mathrm{h})$ to ensure surface growth kinetics, rather than diffusion.

\section{c. Tip Decoration and Dynamic Force Spectroscopy (DFS). Prior to DFS} determinations, ACP substrates were prepared by rapid mixture of ice-cold $1 \mathrm{~mL}$ $\mathrm{CaCl}_{2}(1 \mathrm{M})$ and $99 \mathrm{ml} \mathrm{Na} \mathrm{HPO}_{4}(10 \mathrm{mM})$ according to the previously published methods. ${ }^{3-5}$ After filtration using $200 \mathrm{~nm}$ cellulose acetate membrane, the precipitated particles were washed with ice-cold water $(18.2 \mathrm{M} \Omega \cdot \mathrm{cm})$ and anhydrous ethanol (99.9\%), respectively. Collected particles were then immediately freeze-dried at $-70{ }^{\circ} \mathrm{C}$ and stored in a dry incubator ${ }^{5}$ for subsequent experiments. ACP particles were pressed at $15-20 \mathrm{MPa}$ for 5-10 min at $25{ }^{\circ} \mathrm{C}$ to form an ACP substrate for DFS experiments. ${ }^{6,7}$ The phase of the obtained substrates was confirmed as ACP by X-ray diffraction (XRD) (Bruker D8, Billerica, MA) analyses.

Moreover, tip decoration methods have been described by Newcomb et al. ${ }^{8}$ In short, four self-assembling monomers of 11-amino-1-undecanethiol hydrochloride (99\%), 11-mercaptoundecylphosphoric acid (95\%), 12-mercaptododecanoic acid (96\%), and 1,11-undecanethiol (99\%) for tip functionalization were purchased from Sigma-Aldrich. The bare $\mathrm{Si}_{3} \mathrm{~N}_{4}$ probes with silicon as tip and silicon nitride as the cantilever (Bruker, SNL-10) were cleaned under a plasma cleaner (PDG-MG, China) for about $5 \mathrm{~min}$, soaked in acetone for $30 \mathrm{~min}$, and then coated with gold (Au) using thermal evaporation by an ion sputtering apparatus (model JFC-1600, JEOL, Japan), followed by rinsing with anhydrous ethanol. The gold-coated probes were immersed 
in ethanol with $50 \mathrm{nM}$ alkane thiol for $12 \mathrm{~h}$ for tip functionalization of $\mathrm{PO}_{3}{ }^{-}, \mathrm{NH}_{3}{ }^{+}$and $\mathrm{CH}_{3}$ groups, and the tips containing 12-mercaptododecanoic acid were functionalized for $\mathrm{COO}^{-}$group in a solution of ethanol and acetic acid (95: 5). ${ }^{8}$ After functionalization, probes were incubated and washed in ethanol prior to DFS experiments.

DFS experiments at the mica or ACP interface were conducted in a fluid cell filled with newly prepared acidic supersaturated solution $\left(\sigma_{\mathrm{DCPD}}=0.168, I S=0.15 \mathrm{M}, \mathrm{pH}\right.$ 5.6) or alkaline supersaturated solution $\left(\sigma_{\mathrm{HAP}}=13.6, I S=0.15 \mathrm{M}, \mathrm{pH} 8.0\right)$. The criterion for selecting $\sigma$ values used in DFS experiments is that the ACP substrates are at dynamic equilibrium with dissolution and growth to ensure a relatively smooth surface needed for the DFS experiments. In order to obtain relatively realistic force-distance curves, the thermal calibration $\operatorname{method}^{9}$ was utilized at the beginning of the experiment to calibrate the inverse optical lever sensitivity (InvOLS) and spring constant of each cantilever of the functionalized probes. For each DFS experiment, five retraction velocities, including 20, 200, 1040, 1900, and $3910 \mathrm{~nm} / \mathrm{s}$, were selected at a constant approach velocity of $200 \mathrm{~nm} / \mathrm{s}$ and a dwell time of $1 \mathrm{~s}$ both at the substrate and retracted from the substrate with a $2 \mathrm{~nm}$ deflection trigger point. In addition, ACP did exist in a stable state during 2-3 h of Raman detection, a fresh ACP substrate was necessarily replaced every $2-3 \mathrm{~h}$ to make sure phase stability of ACP existed in the DFS experiments. Force-distance curves were collected at 256 positions on $2 \times 2 \mu \mathrm{m}^{2}$ of mica or ACP substrate, and at least 50 force-distance curves were chosen at each retraction velocity to explain local heterogeneities. 
The DFS data analysis has been proposed by Friddle et al. ${ }^{10}$ to study the energy profile of both near-equilibrium and far-from-equilibrium regimes using the multiple bond theory ${ }^{10}$, which shows that rupture force increases with the logarithm of loading rate, and by fitting the data, we can obtain both the physical distance between the bound and unbound states $\left(x_{\mathrm{t}}\right)$ and the equilibrium force $\left(f_{\mathrm{eq}}\right)$ under near-equilibrium state at a retraction velocity of zero, which can further evaluate the free energy of binding $\left(\Delta \mathrm{G}_{\mathrm{b}}\right)$, representing a quasi-equilibrium case where the work $W$ is required to break a bond without pulling rate. The equations used for fitting data to get experimental values $x_{\mathrm{t}}$ and $f_{\text {eq }}$ are as follows: ${ }^{10}$

$$
\begin{gathered}
<f>_{N} \cong f_{e q}+N f_{\beta} e^{\frac{N}{R\left(\frac{f_{e q}}{N}\right)}} E_{1} \frac{N}{R\left(\frac{f_{e q}}{N}\right)} \\
\mathrm{R}\left(\frac{f_{e q}}{N}\right)=\frac{r}{k_{u}\left(\frac{f_{e q}}{N}\right) f_{\beta}}, E_{1}(Z)=\int_{Z}^{\infty} \frac{e^{-s}}{s} d s
\end{gathered}
$$

where $f_{\beta}=k_{\mathrm{B}} \mathrm{T} / x_{\mathrm{t}}, k_{\mathrm{B}}$ is Boltzmann constant, $r$ is the loading rate, and $N$ is the number of bonds. The binding free energy of the bound state can then be determined from:

$$
\Delta \mathrm{G}_{\mathrm{b}}=k_{\mathrm{B}} \mathrm{T} \ln \left(\frac{f_{e q} x_{t}}{k_{B} T}\right)+f_{e q} x_{t}+k_{B} T
$$

Real-Time Raman Spectroscopy. A confocal Raman microscope (Horiba LabRAM HR800) was used to observe the occurrence and phase transformation of nucleated Ca-P particles on mica in supersaturated DCPD $\left(\sigma_{\mathrm{DCPD}}=0.799, I S=0.15 \mathrm{M}, \mathrm{pH} 5.6\right.$, $\left.25^{\circ} \mathrm{C}\right)$ or $\operatorname{HAP}\left(\sigma_{\mathrm{HAP}}=32.3, I S=0.15 \mathrm{M}, \mathrm{pH} 8.0,25^{\circ} \mathrm{C}\right)$ solutions in the absence and 
presence of HA (0.01-0.5 mg/L). Following calibration using the characteristic band of silicon at $520.7 \mathrm{~cm}^{-1}$, the Raman spectra were obtained by using a laser $532 \mathrm{~nm}$ with $50 \mu \mathrm{m}$ confocal hole and a 600 lines/mm grating under a $50 \mathrm{x}$ microscope objective (Olympus, MLPlanTL N) at $25^{\circ} \mathrm{C}$ in a liquid cell. For each Raman measurement, the spectra were collected twice in order to decrease the single noise. The data collected above were analyzed by the LabSpec 6 software.

High-Resolution Transmission Electron Microscopy (HRTEM). According to the real-time Raman spectra of the phase evolution of nucleated particles (Figure 2), initial ACP was stabilized within $5 \mathrm{~h}$ at $\mathrm{pH} 5.6$ and $12 \mathrm{~h}$ at $\mathrm{pH}$ 8.0. Thus, we just needed to collect ACP particles for HRTEM observation during the amorphous period. Additionally, more particles formed in $6 \mathrm{~h}$ at $\mathrm{pH} 8.0$ allowing for better observation compared with that in $2 \mathrm{~h}$. The precipitates isolated from supersaturated DCPD $\left(\sigma_{\mathrm{DCPD}}=0.799, I S=0.15 \mathrm{M}, \mathrm{pH} 5.6,25{ }^{\circ} \mathrm{C}, 2 \mathrm{~h}\right)$ or $\mathrm{HAP}\left(\sigma_{\mathrm{HAP}}=32.3, I S=0.15 \mathrm{M}\right.$, $\left.\mathrm{pH}=8.0,25{ }^{\circ} \mathrm{C}, 6 \mathrm{~h}\right)$ solutions in the absence and presence of HA $(0.01-0.5 \mathrm{mg} / \mathrm{L})$ were extracted by $10000 \mathrm{r} / \mathrm{min}$ at $25{ }^{\circ} \mathrm{C}$ for 2 min using a $5810 \mathrm{R}$ bench freezing centrifuge (Eppendorf, Germany). Anhydrous ethanol ( $\geq 99.9 \%$, Merck KGaA) was utilized to further separate and extract these precipitates three times in order to stabilize the precipitates. Finally, the collected precipitates were placed on a carbon-coated copper grid for HRTEM experiments. A Cs-corrected TEM (FEL Titan $\mathrm{G}^{2}$ 60-300) with the EDX detector was used for characterizing the phases of the precipitates at an acceleration voltage of $200 \mathrm{kV}$. In order to reduce the effect of the electron beam on the phase transformation and prevent possible hydration phases 
from decomposing, liquid nitrogen was used during the whole HRTEM experiments.

Parameters of $d$-spacing values were matched with JCPDE card for DCPD (11-0293), OCP (44-0788) and HAP (09-0432).

Table S1. Solution conditions used in all experiments.

\begin{tabular}{ccccccc}
\hline \multirow{2}{*}{ Experiments } & \multirow{2}{*}{$\mathrm{pH}$} & $\sigma$ & \multicolumn{5}{c}{$\mathrm{c}(\mathrm{mM})$} \\
\cline { 3 - 6 } & & & $\mathrm{CaCl}_{2}$ & $\mathrm{KH}_{2} \mathrm{PO}_{4}$ & $\mathrm{NaCl}$ & $\mathrm{KOH}$ \\
\hline Nucleation & 5.6 & 0.748 & 12.3 & 12.3 & 102 & 1.07 \\
& & 0.799 & 12.7 & 12.7 & 101 & 1.11 \\
& & 0.850 & 13.1 & 13.1 & 99.5 & 1.16 \\
& & 0.900 & 13.5 & 13.5 & 98 & 1.20 \\
& & & & & & \\
& & 32.1 & 1.86 & 1.116 & 142 & 1.08 \\
Raman/HRTEM & 5.6 & 1.88 & 1.128 & 142 & 1.09 \\
& & 32.6 & 1.90 & 1.140 & 141 & 1.10 \\
DFS & 32.9 & 1.92 & 1.152 & 141 & 1.11 \\
& & 0.799 & 12.7 & 12.7 & 101 & 1.11 \\
& 5.6 & 32.3 & 1.88 & 1.128 & 142 & 1.09 \\
& 8.0 & 0.168 & 7.9 & 9.7 & 119 & 0.162 \\
& 13.6 & 0.705 & 0.422 & 147 & 0.404 \\
\hline
\end{tabular}


Table S2. Raman peak assignments of mica and calcium phosphates.

\begin{tabular}{|c|c|c|}
\hline Minerals & Observed $\left(\mathrm{cm}^{-1}\right)$ & Assignments \\
\hline \multirow[t]{7}{*}{ Mica $^{11}$} & 407 & M2 xz-trans. +Od z-trans. +Oc,e xz-trans. \\
\hline & 637 & Onb yz-trans. +Obr-yz-trans. \\
\hline & 701 & Onb z-trans. +Obr-z-trans. +M2-Ob stretch \\
\hline & 752 & Oa-M2-Ob bend \\
\hline & 911 & Tetrahedral breathing \\
\hline & 953 & T-Onb stretch $\left(v_{1}\right)$ \\
\hline & 1113 & T1,2-Oc,d xy-stretch $\left(v_{10}\right)$ \\
\hline \multirow[t]{3}{*}{$\mathrm{DCPD}^{12,13}$} & $980-985$ & $v_{1} \mathrm{PO}_{4}{ }^{3-}$ \\
\hline & 413 & $v_{2} \mathrm{PO}_{4}{ }^{3-}$ \\
\hline & 577,587 & $v_{4} \mathrm{PO}_{4}{ }^{3-}$ \\
\hline \multirow[t]{4}{*}{$\mathrm{OCP}^{12}$} & $955-957$ & $v_{1} \mathrm{PO}_{4}{ }^{3-}$ \\
\hline & 413 & $v_{2} \mathrm{PO}_{4}{ }^{3-}$ \\
\hline & $578-608$ & $v_{4} \mathrm{PO}_{4}{ }^{3-}$ \\
\hline & 1010 & $v_{1} \mathrm{HPO}_{4}{ }^{2-}$ \\
\hline \multirow[t]{3}{*}{$\mathrm{HAP}^{12}$} & 960 & $v_{1} \mathrm{PO}_{4}{ }^{3-}$ \\
\hline & 433,448 & $v_{2} \mathrm{PO}_{4}{ }^{3-}$ \\
\hline & $580-608$ & $v_{4} \mathrm{PO}_{4}{ }^{3-}$ \\
\hline
\end{tabular}


Table S3. Raman peak assignments of HA.

\begin{tabular}{|c|c|c|}
\hline Organic ligands & Observed $\left(\mathrm{cm}^{-1}\right)$ & assignments \\
\hline \multirow[t]{2}{*}{$-\mathrm{COOH}^{14}$} & $1540-1650$ & $\mathrm{COO}^{-}$, asym. stretch \\
\hline & $1300-1420$ & $\mathrm{COO}^{-}$, sym. stretch \\
\hline$-\mathrm{PO}_{4}{ }^{15}$ & $1000-1100$ & $\begin{array}{l}\mathrm{PO}_{2}^{-}, \text {sym. stretch } \\
-\mathrm{C}-\mathrm{O}-\mathrm{P}-\mathrm{O}-\mathrm{C} \text { stretch }\end{array}$ \\
\hline \multirow[t]{2}{*}{$-\mathrm{NH}_{2}{ }^{16}$} & $3250-3300$ & $\mathrm{NH}_{2}$, sym. stretch \\
\hline & $3330-3400$ & $\mathrm{NH}_{2}$, asym. stretch \\
\hline \multirow[t]{2}{*}{$-\mathrm{CH}_{3}{ }^{17}$} & 2965-2969 & $\mathrm{CH}_{3}$, asym. stretch \\
\hline & $2883-2884$ & $\mathrm{CH}_{3}$, sym. stretch \\
\hline$-\mathrm{Ph}^{18}$ & $720-830$ & Benzene ring vibration \\
\hline$-\mathrm{NO}_{2}{ }^{19}$ & $1275-1282$ & $\mathrm{NO}_{2}$, sym. stretch \\
\hline$-\mathrm{CHO}^{20}$ & $1720-1740$ & $\mathrm{C}=\mathrm{O}$, stretch \\
\hline$-\mathrm{C}=\mathrm{C}=\mathrm{O}^{21}$ & 2049 & $\mathrm{C}=\mathrm{C}=\mathrm{O}$, asym. stretch \\
\hline$-\mathrm{C} \equiv \mathrm{N}^{22}$ & $2000-2220$ & $\mathrm{C} \equiv \mathrm{N}$, stretch \\
\hline \multirow[t]{2}{*}{$-\mathrm{C} \equiv \mathrm{C}-{ }^{23}$} & $2231-2316$ & $\mathrm{C} \equiv \mathrm{C}$, sym. stretch \\
\hline & $3206-3214$ & $\mathrm{O}-\mathrm{H}$, asym. stretch \\
\hline \multirow[t]{2}{*}{$\mathrm{H}_{2} \mathrm{O}^{24}$} & $3430-3438$ & $\mathrm{O}-\mathrm{H}$, sym. stretch \\
\hline & $1634-1638$ & $\mathrm{O}-\mathrm{H}$, deformation vibration \\
\hline
\end{tabular}


Table S4. $\Delta \mathrm{G}_{\mathrm{b}}$ and corresponding fitting parameters from DFS data ( $\mathrm{x}_{\mathrm{t}}$ : distance to transition between bound and unbound states, $\mathrm{f}_{\mathrm{eq}}$ : equilibrium force). All values are represented as mean \pm standard deviation)

\begin{tabular}{|c|c|c|c|c|c|}
\hline \multirow{2}{*}{ pH } & \multirow{2}{*}{ Minerals } & \multirow{2}{*}{$\begin{array}{l}\text { Organic } \\
\text { ligands }\end{array}$} & \multicolumn{2}{|c|}{ Fitting parameters } & \multirow{2}{*}{$\begin{array}{c}-\Delta G_{b} \\
(K J / m o l)\end{array}$} \\
\hline & & & $\mathbf{x}_{\mathrm{t}}(\AA)$ & $f_{e q}(p N)$ & \\
\hline \multirow[t]{8}{*}{5.6} & mica & $\mathrm{COO}^{-}$ & $0.45 \pm 0.046$ & $201.65 \pm 4.29$ & $9.94 \pm 0.68$ \\
\hline & & $\mathrm{PO}_{3}^{-}$ & $0.35 \pm 0.026$ & $163.14 \pm 6.78$ & $6.77 \pm 0.20$ \\
\hline & & $\mathrm{NH}_{3}{ }^{+}$ & $0.37 \pm 0.032$ & $145.89 \pm 2.01$ & $6.43 \pm 0.45$ \\
\hline & & $\mathrm{CH}_{3}$ & $0.33 \pm 0.022$ & $76.53 \pm 2.47$ & $2.83 \pm 0.32$ \\
\hline & $\mathrm{ACP}$ & $\mathrm{COO}^{-}$ & $0.61 \pm 0.058$ & $350.89 \pm 6.56$ & $19.43 \pm 1.72$ \\
\hline & & $\mathrm{PO}_{3}^{-}$ & $0.37 \pm 0.033$ & $258.22 \pm 5.62$ & $10.22 \pm 0.89$ \\
\hline & & $\mathrm{NH}_{3}{ }^{+}$ & $0.33 \pm 0.014$ & $229.20 \pm 2.89$ & $8.59 \pm 0.32$ \\
\hline & & $\mathrm{CH}_{3}$ & $0.28 \pm 0.026$ & $92.21 \pm 2.64$ & $2.88 \pm 0.46$ \\
\hline \multirow[t]{8}{*}{8.0} & mica & $\mathrm{COO}^{-}$ & $0.44 \pm 0.032$ & $166.23 \pm 5.44$ & $8.25 \pm 0.73$ \\
\hline & & $\mathrm{PO}_{3}^{-}$ & $0.39 \pm 0.035$ & $132.63 \pm 5.26$ & $6.20 \pm 0.72$ \\
\hline & & $\mathrm{NH}_{3}{ }^{+}$ & $0.37 \pm 0.031$ & $99.51 \pm 5.95$ & $4.40 \pm 0.43$ \\
\hline & & $\mathrm{CH}_{3}$ & $0.37 \pm 0.020$ & $66.94 \pm 4.02$ & $2.65 \pm 0.30$ \\
\hline & $\mathrm{ACP}$ & $\mathrm{COO}^{-}$ & $0.45 \pm 0.036$ & $378.11 \pm 3.99$ & $16.23 \pm 0.90$ \\
\hline & & $\mathrm{PO}_{3}^{-}$ & $0.37 \pm 0.031$ & $280.45 \pm 6.76$ & $10.93 \pm 0.60$ \\
\hline & & $\mathrm{NH}_{3}{ }^{+}$ & $0.37 \pm 0.023$ & $211.91 \pm 6.74$ & $8.79 \pm 0.62$ \\
\hline & & $\mathrm{CH}_{3}$ & $0.35 \pm 0.031$ & $80.53 \pm 2.94$ & $3.29 \pm 0.45$ \\
\hline
\end{tabular}



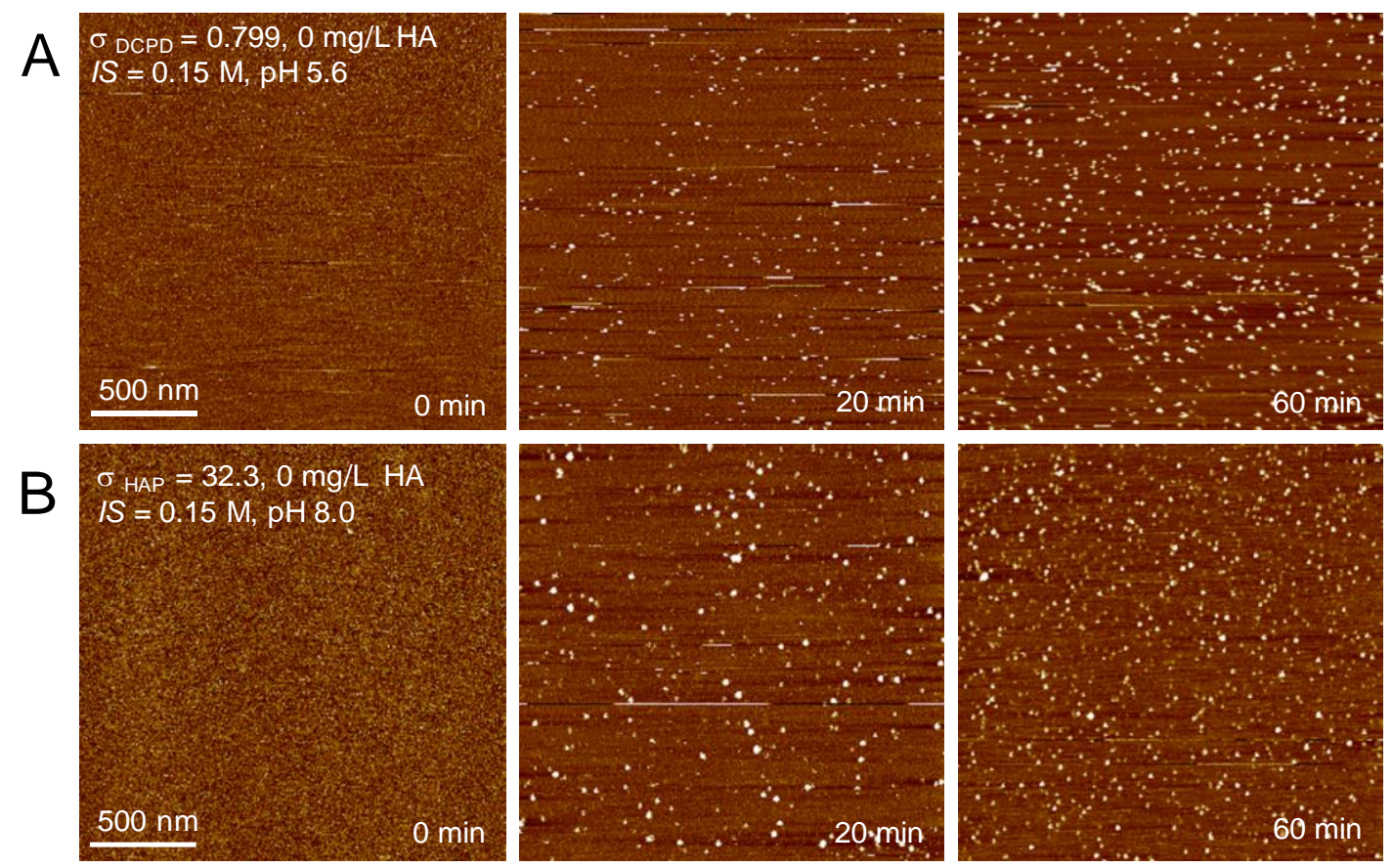

Figure S1. AFM imaging of a representative ACP nucleation event of (A) DCPD or (B) HAP with time on a mica surface in solutions supersaturated with respect to $\operatorname{DCPD}\left(\sigma_{\mathrm{DCPD}}=0.799, I S=0.15 \mathrm{M}, \mathrm{pH} 5.6,25^{\circ} \mathrm{C}\right)$ or $\mathrm{HAP}\left(\sigma_{\mathrm{HAP}}=32.3, I S=0.15 \mathrm{M}\right.$, $\left.\mathrm{pH} 8.0,25^{\circ} \mathrm{C}\right)$ in the absence of $\mathrm{HA}$, respectively.
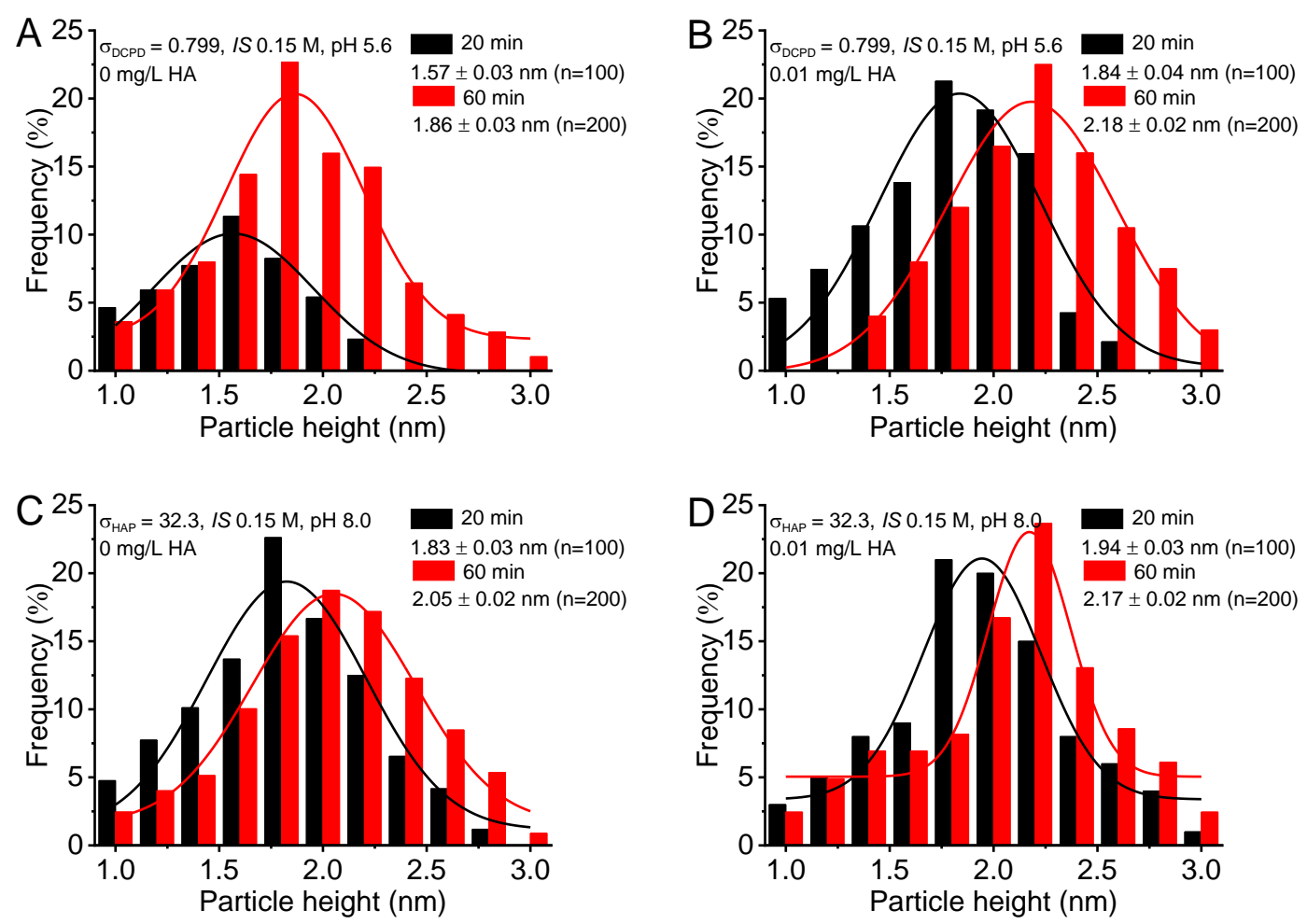

Figure S2. (A)-(D) Particle size (in height measured by AFM) distributions (corresponding to results in Figures 1 and S1). 


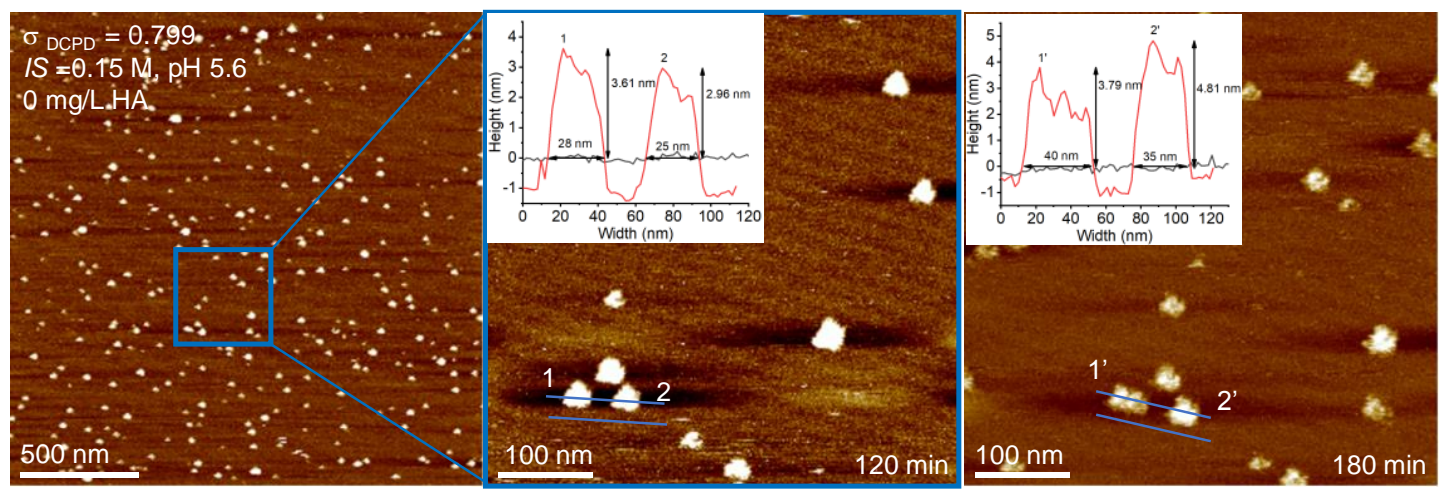

Figure S3. Particle aggregation and growth after 120 and $180 \mathrm{~min}$ of reactions in a supersaturated solution $\left(\sigma_{\mathrm{DCPD}}=0.799, I S=0.15 \mathrm{M}, \mathrm{pH} 5.6,25^{\circ} \mathrm{C}\right)$ in the absence of HA.

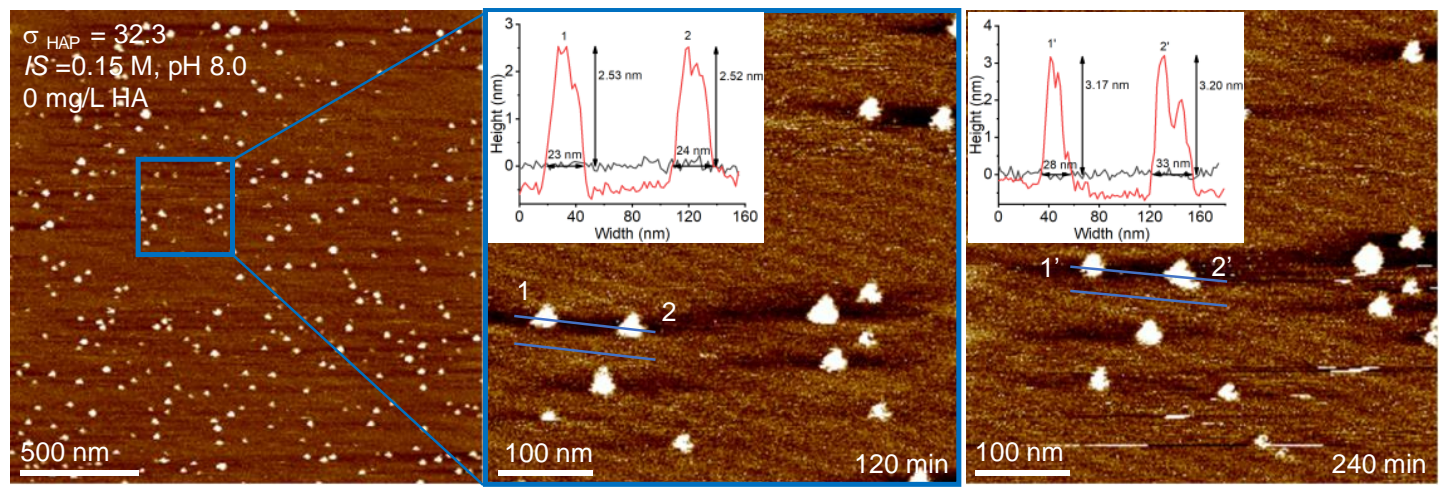

Figure S4. Particle aggregation and growth after 120 and $240 \mathrm{~min}$ of reactions in a supersaturated solution $\left(\sigma_{\mathrm{HAP}}=32.3, I S=0.15 \mathrm{M}, \mathrm{pH} 8.0,25^{\circ} \mathrm{C}\right)$ in the absence of HA.

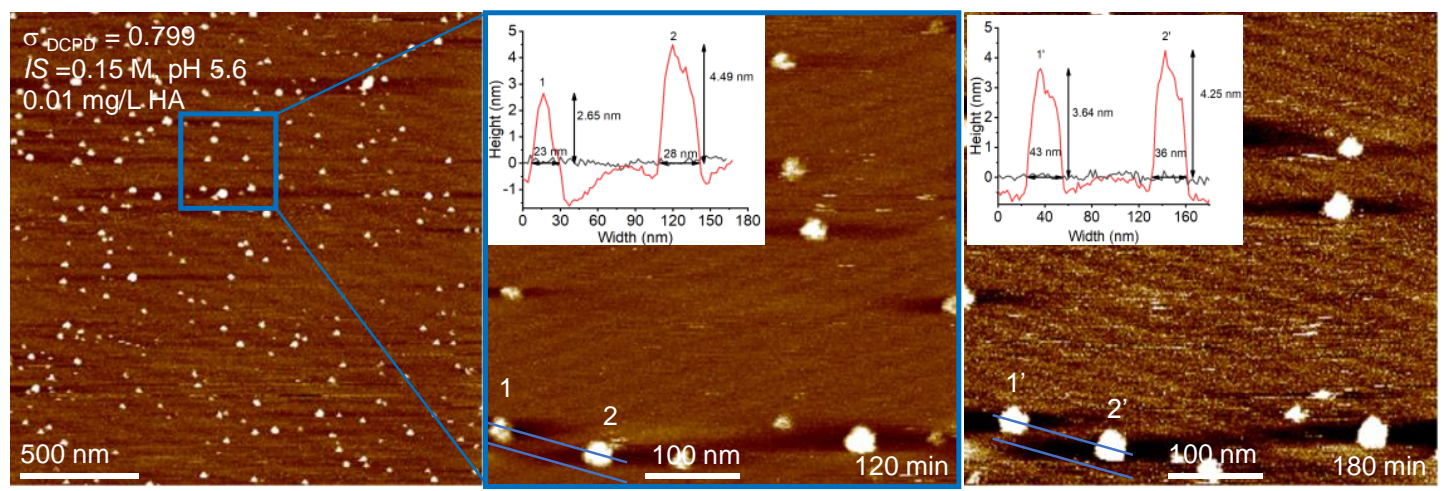

Figure S5. Particle aggregation and growth after 120 and $180 \mathrm{~min}$ of reactions in a supersaturated solution $\left(\sigma_{\mathrm{DCPD}}=0.799, I S=0.15 \mathrm{M}, \mathrm{pH} 5.6,25^{\circ} \mathrm{C}\right)$ in the presence of $0.01 \mathrm{mg} / \mathrm{L} \mathrm{HA}$. 


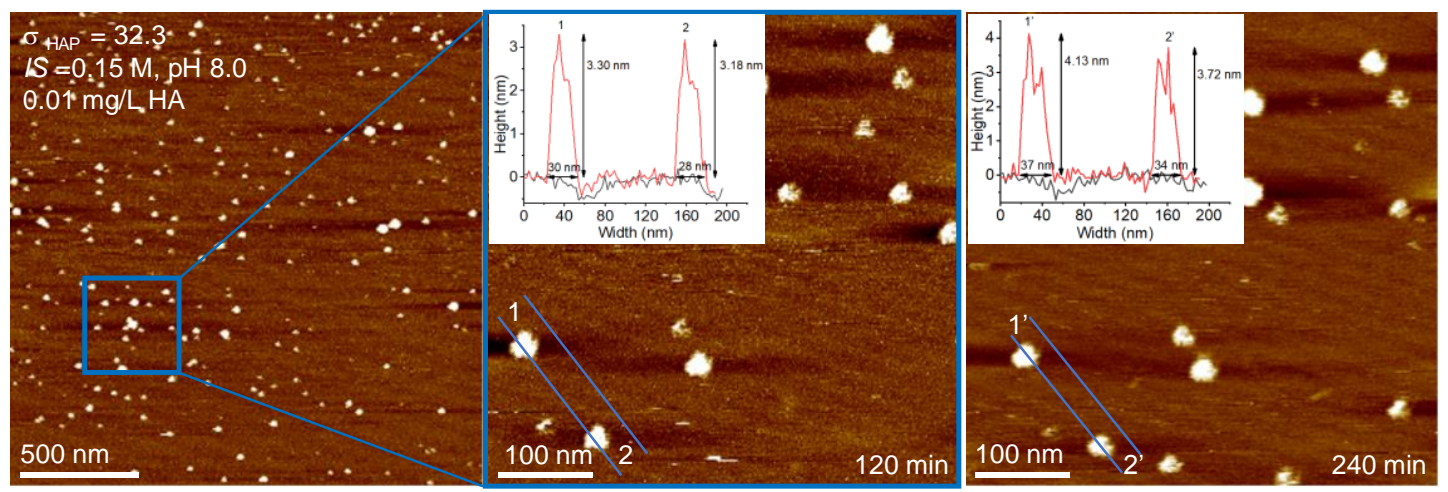

Figure S6. Particle aggregation and growth after 120 and $240 \mathrm{~min}$ of reactions in a supersaturated solution $\left(\sigma_{\mathrm{HAP}}=32.3, I S=0.15 \mathrm{M}, \mathrm{pH} 8.0,25{ }^{\circ} \mathrm{C}\right)$ in the presence of $0.01 \mathrm{mg} / \mathrm{L} \mathrm{HA}$.

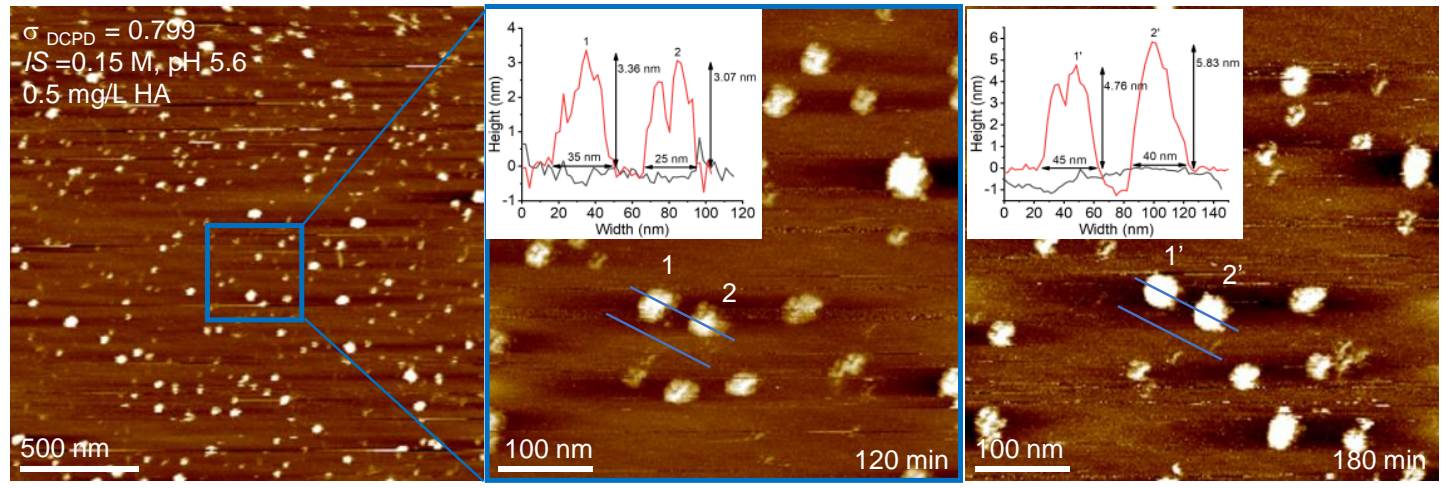

Figure S7. Particle aggregation and growth after 120 and $180 \mathrm{~min}$ of reactions in a supersaturated solution $\left(\sigma_{\mathrm{DCPD}}=0.799, I S=0.15 \mathrm{M}, \mathrm{pH} 5.6,25^{\circ} \mathrm{C}\right)$ in the presence of $0.5 \mathrm{mg} / \mathrm{L} \mathrm{HA}$.

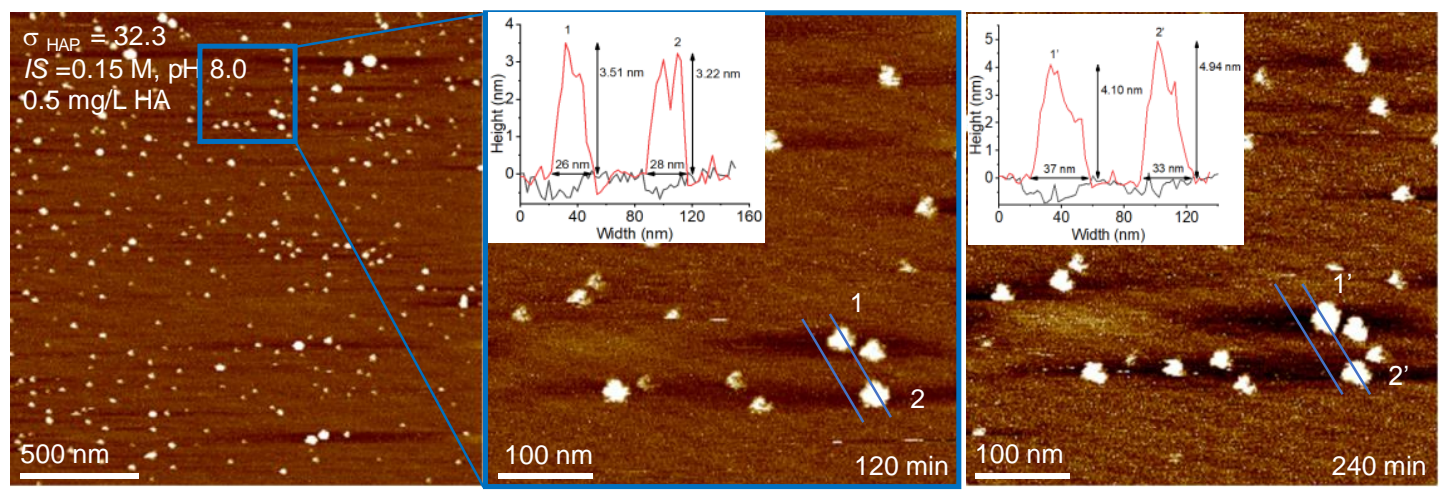

Figure S8. Particle aggregation and growth after 120 and 240 min of reactions in a supersaturated solution $\left(\sigma_{\mathrm{HAP}}=32.3, I S=0.15 \mathrm{M}, \mathrm{pH} 8.0,25{ }^{\circ} \mathrm{C}\right)$ in the presence of $0.5 \mathrm{mg} / \mathrm{L}$ HA. 

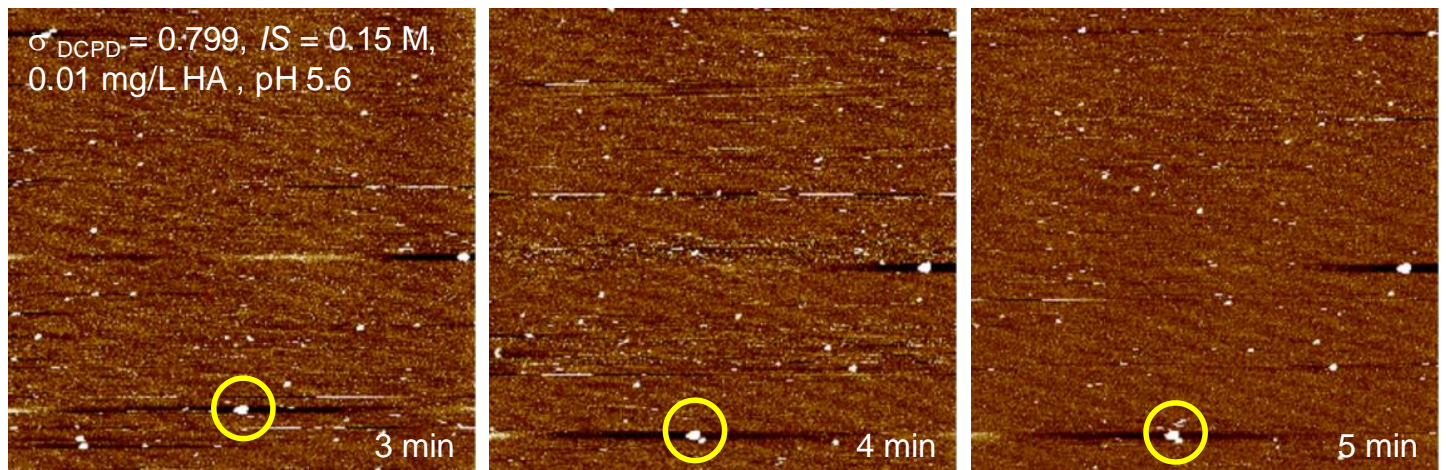

Figure S9. AFM time sequence (height images) showing two particles (yellow circle) aggregated into one larger particle on a mica surface in supersaturated solution $\left(\sigma_{\mathrm{DCPD}}\right.$ $=0.799, I S=0.15 \mathrm{M}, \mathrm{HA}=0.01 \mathrm{mg} / \mathrm{L}, \mathrm{pH} 5.6)$
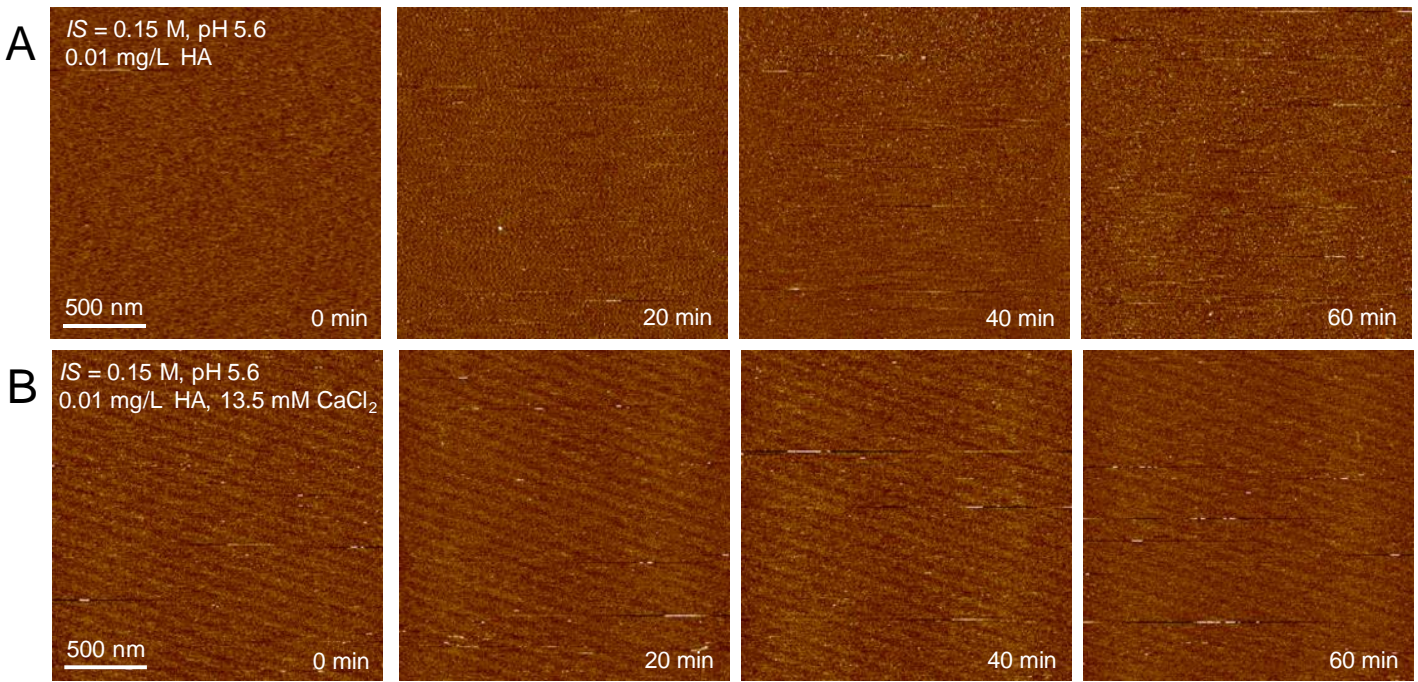

Figure S10. (A)-(B) No particles were detected in solutions of $0.01 \mathrm{mg} / \mathrm{L} \mathrm{HA}$ with and without $\mathrm{Ca}^{2+}$ at $\mathrm{pH}$ 5.6.
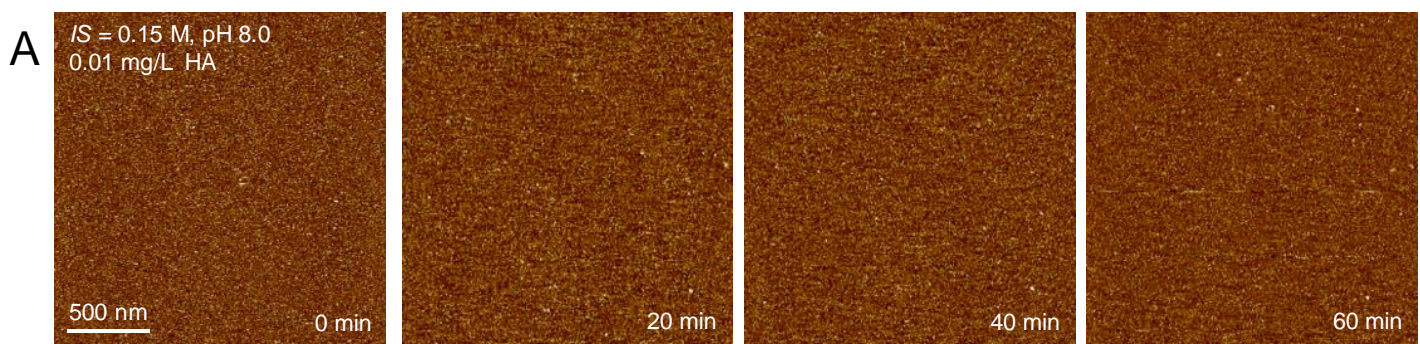

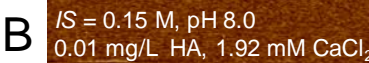
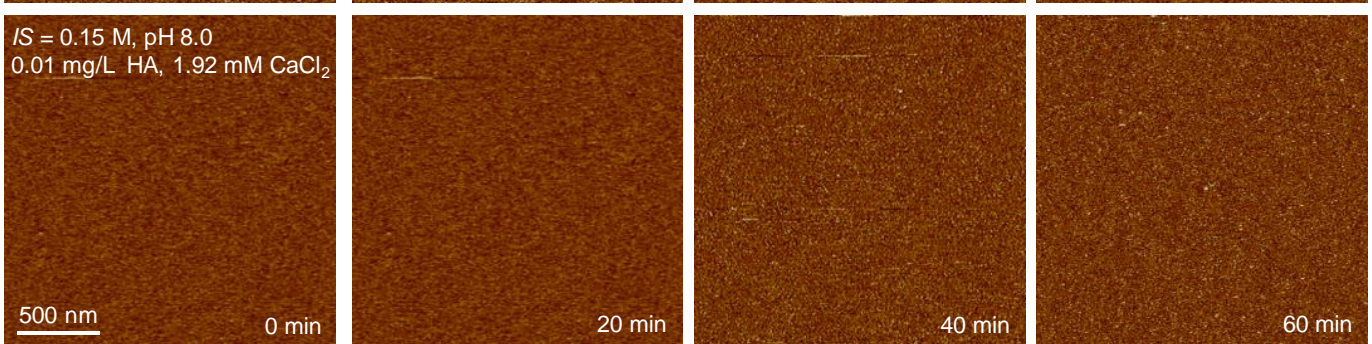

Figure S11. (A)-(B) No particles were detected in solutions of $0.01 \mathrm{mg} / \mathrm{L} \mathrm{HA}$ with and without $\mathrm{Ca}^{2+}$ at $\mathrm{pH}$ 8.0. 

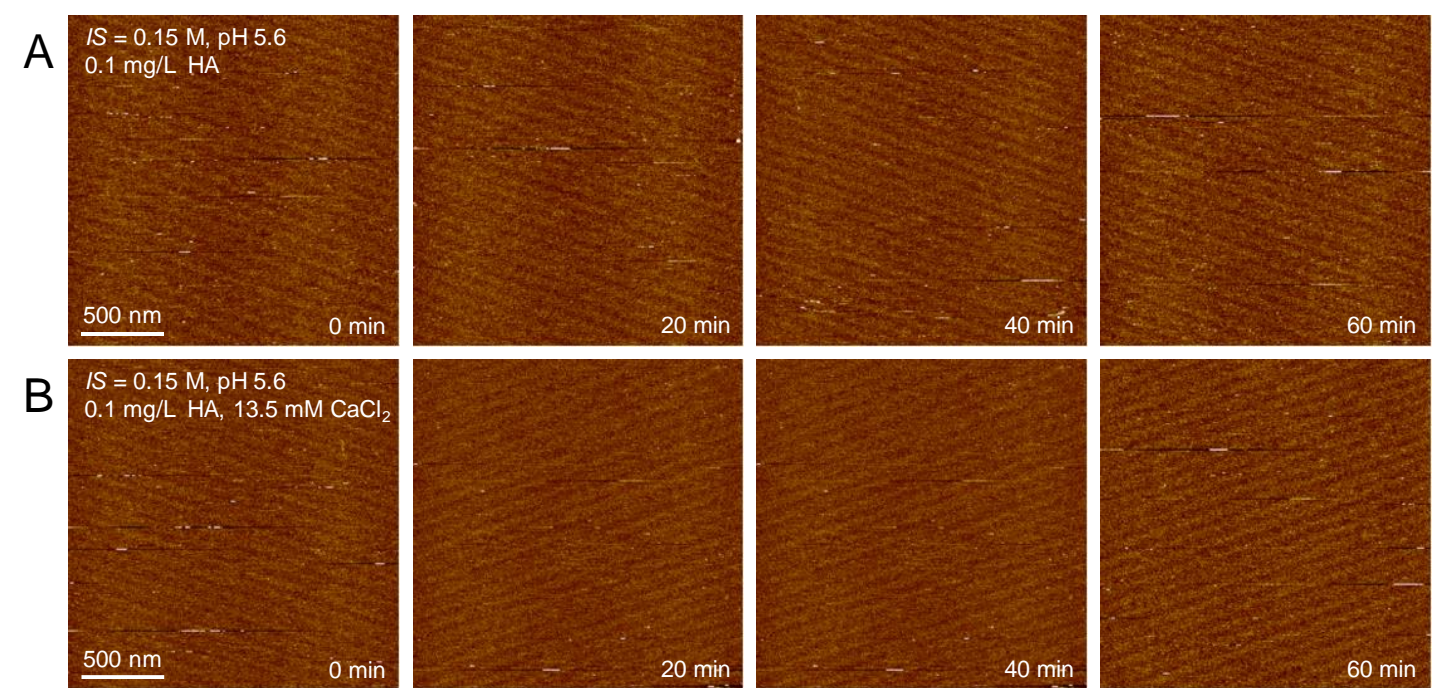

Figure S12. (A)-(B) No particles were detected in solutions of $0.1 \mathrm{mg} / \mathrm{L}$ HA with and without $\mathrm{Ca}^{2+}$ at $\mathrm{pH}$ 5.6.
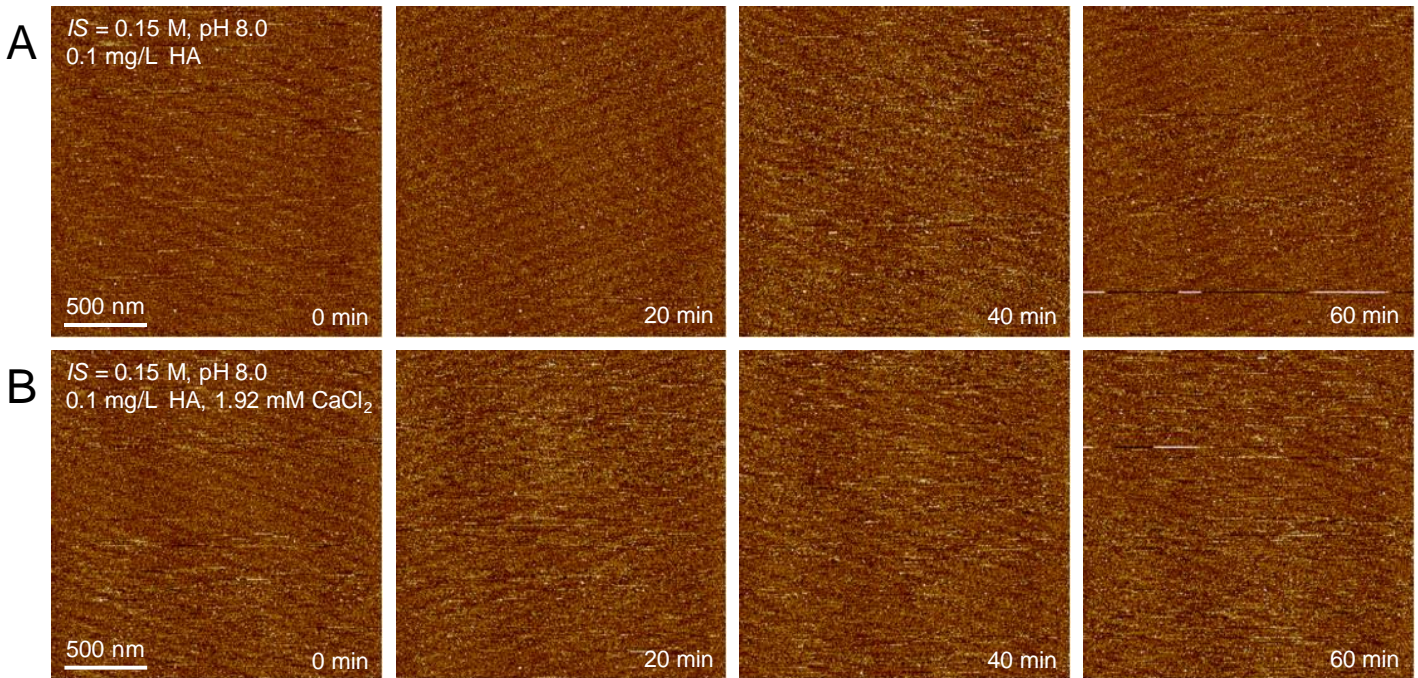

Figure S13. (A)-(B) No particles were detected in solutions of $0.1 \mathrm{mg} / \mathrm{L}$ HA with and without $\mathrm{Ca}^{2+}$ at $\mathrm{pH}$ 8.0.
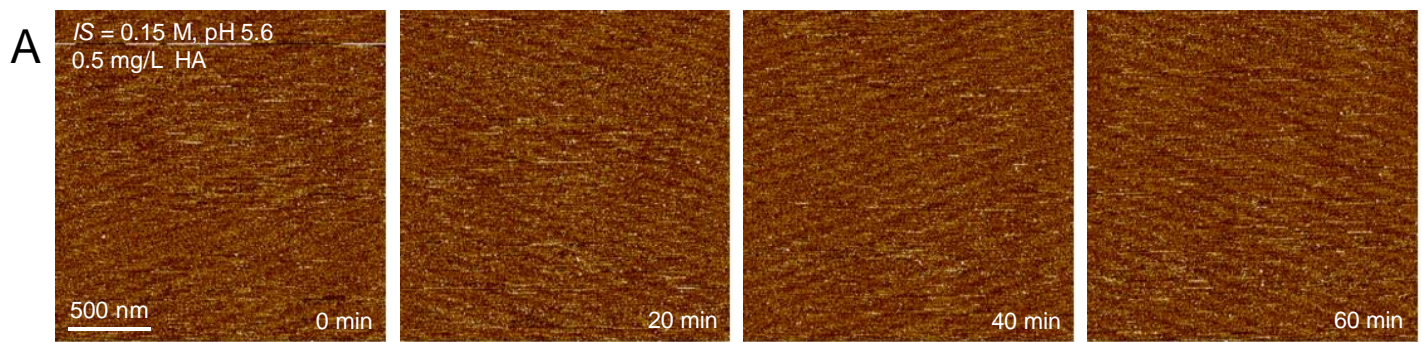

B $\begin{aligned} & I S=0.15 \mathrm{M}, \mathrm{pH} 5.6 \\ & 0.5 \mathrm{mg} / \mathrm{L} \mathrm{HA}, 13.5 \mathrm{mM} \mathrm{CaCl}_{2}\end{aligned}$
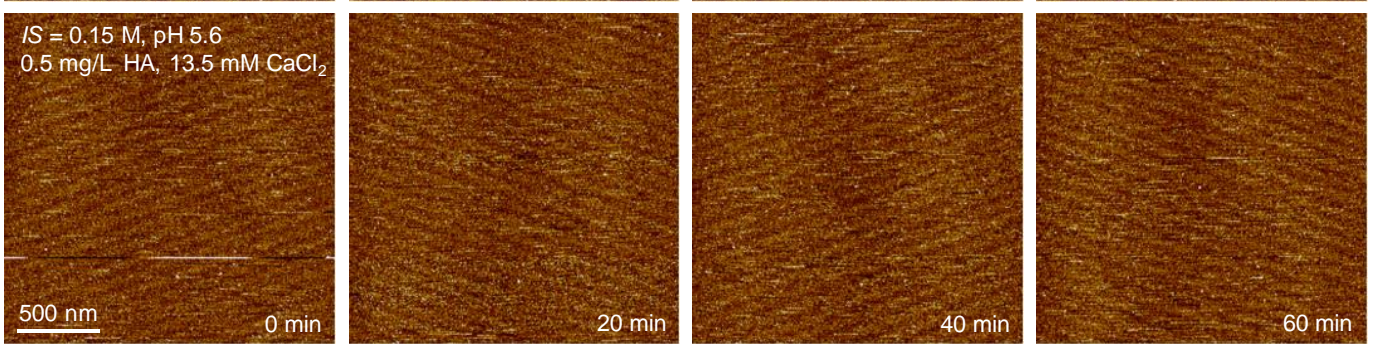

Figure S14. (A)-(B) No particles were detected in solutions of $0.5 \mathrm{mg} / \mathrm{L} \mathrm{HA}$ with and 
without $\mathrm{Ca}^{2+}$ at $\mathrm{pH}$ 5.6.
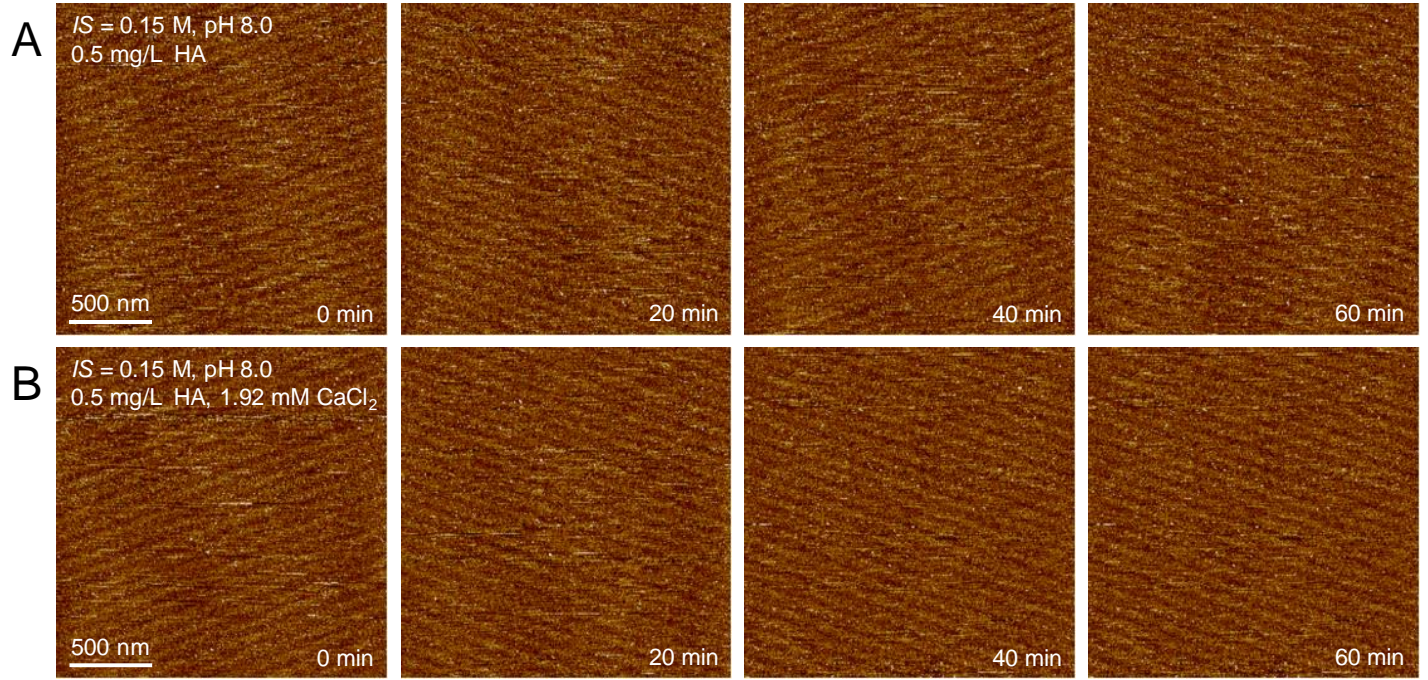

Figure S15. (A)-(B) No particles were detected in solutions of $0.5 \mathrm{mg} / \mathrm{L} \mathrm{HA}$ with and without $\mathrm{Ca}^{2+}$ at $\mathrm{pH}$ 8.0.
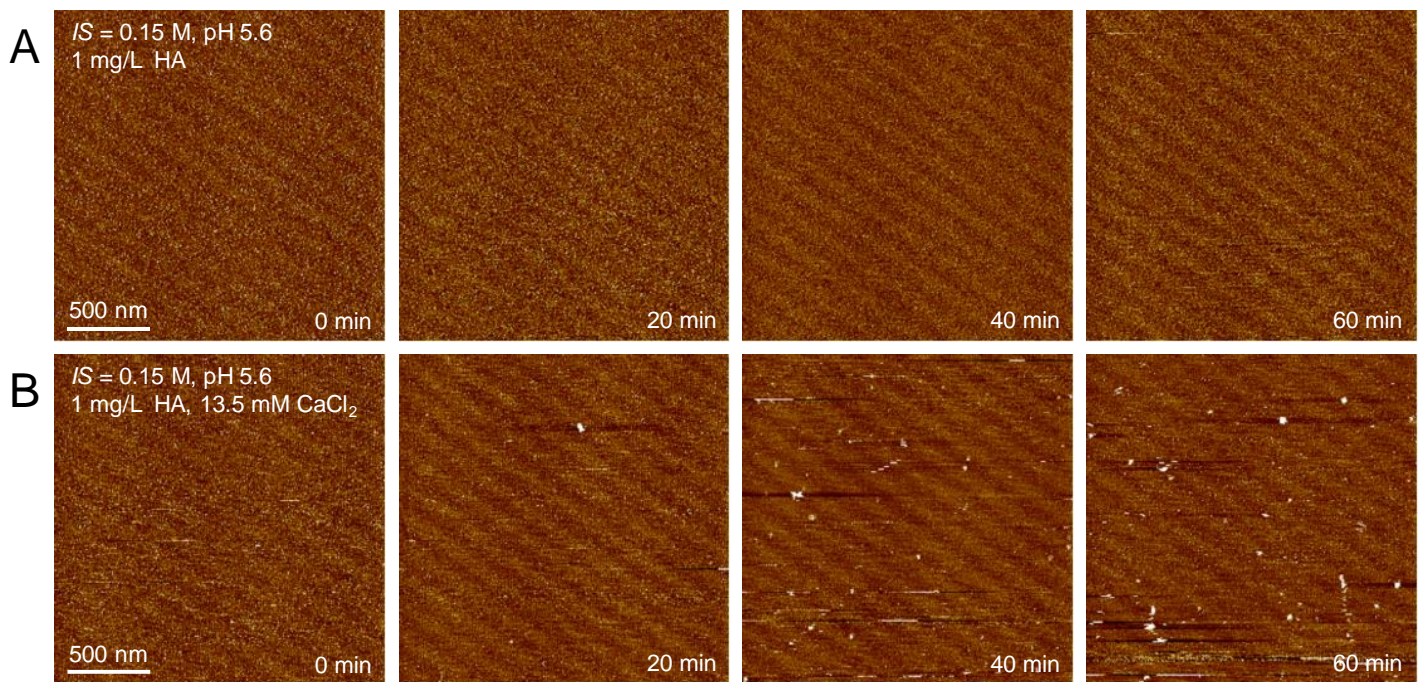

Figure S16. (A)-(B) Particles were detected in solutions of $1.0 \mathrm{mg} / \mathrm{L} \mathrm{HA}$ with $\mathrm{Ca}^{2+}$ at pH 5.6, whereas no particles observed without $\mathrm{Ca}^{2+}$.
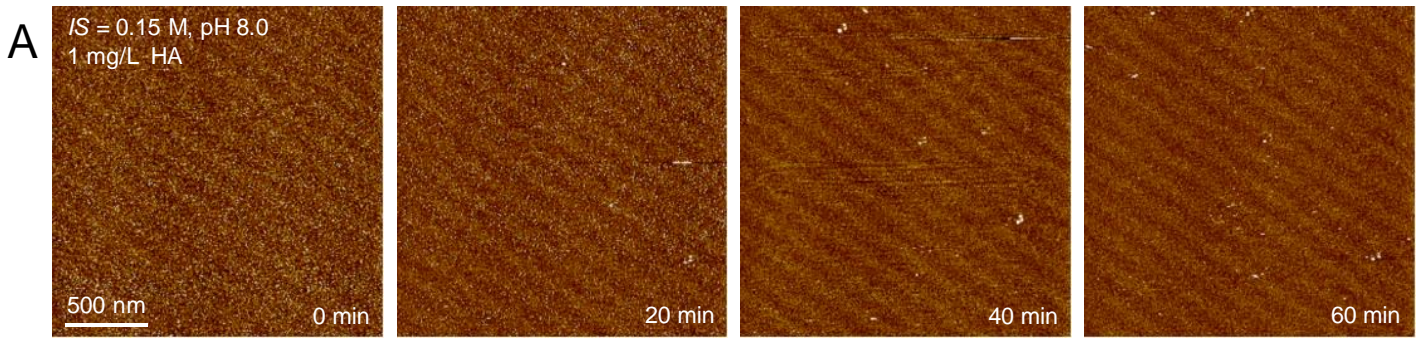

B $\quad$ IS $=0.15 \mathrm{M}, \mathrm{pH} 8.0$
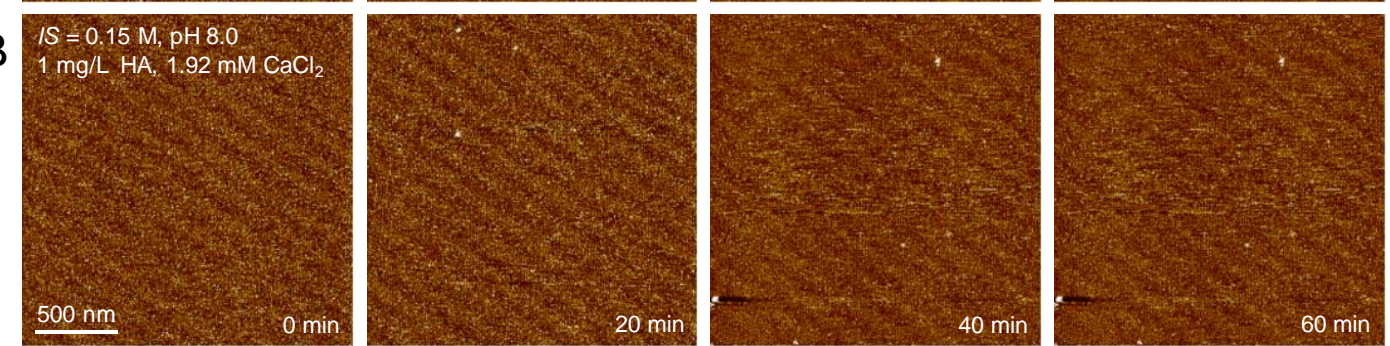
Figure S17. (A)-(B) Particles were detected in solutions of $1.0 \mathrm{mg} / \mathrm{L} \mathrm{HA}$ with and without $\mathrm{Ca}^{2+}$ at $\mathrm{pH}$ 8.0.
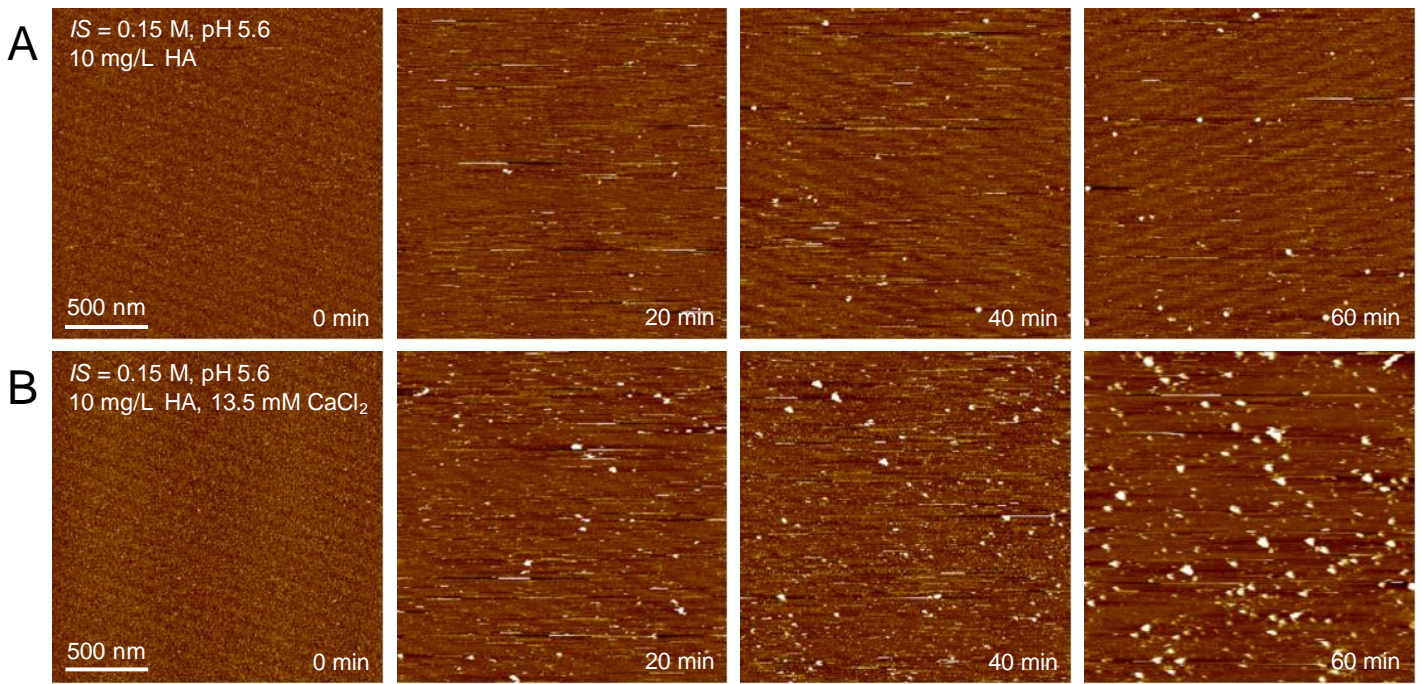

Figure S18. (A)-(B) Particles were detected in solutions of $10 \mathrm{mg} / \mathrm{L}$ HA with and without $\mathrm{Ca}^{2+}$ at $\mathrm{pH}$ 5.6.
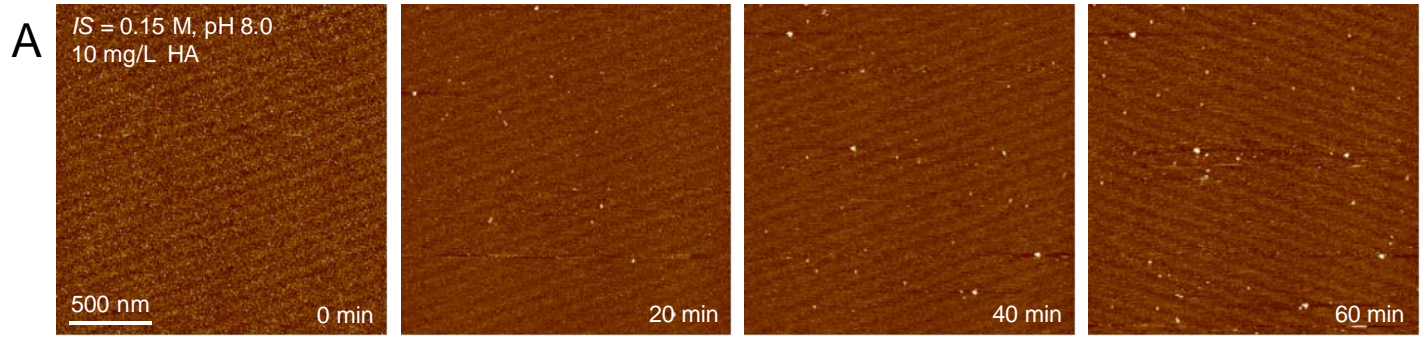

$\mathrm{B}$
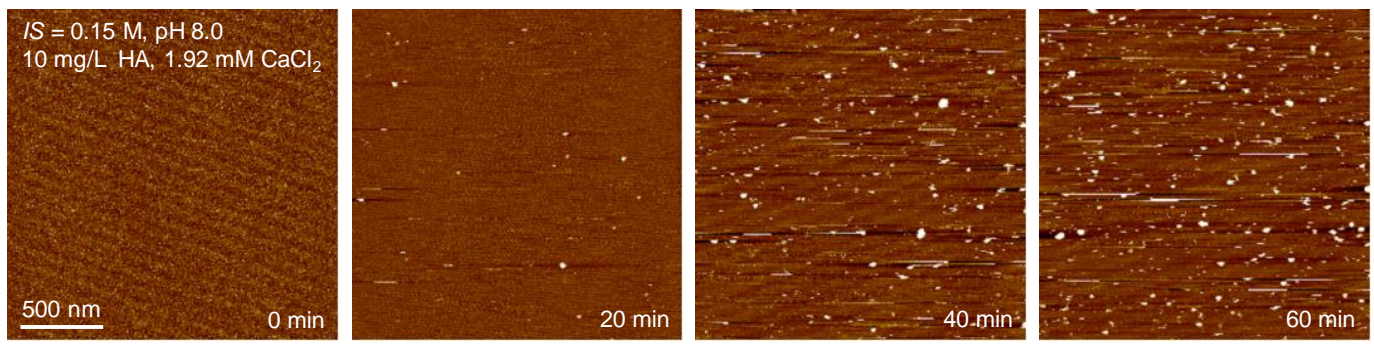

Figure S19. (A)-(B) Particles were detected in solutions of $10 \mathrm{mg} / \mathrm{L} \mathrm{HA}$ with and without $\mathrm{Ca}^{2+}$ at $\mathrm{pH}$ 8.0.

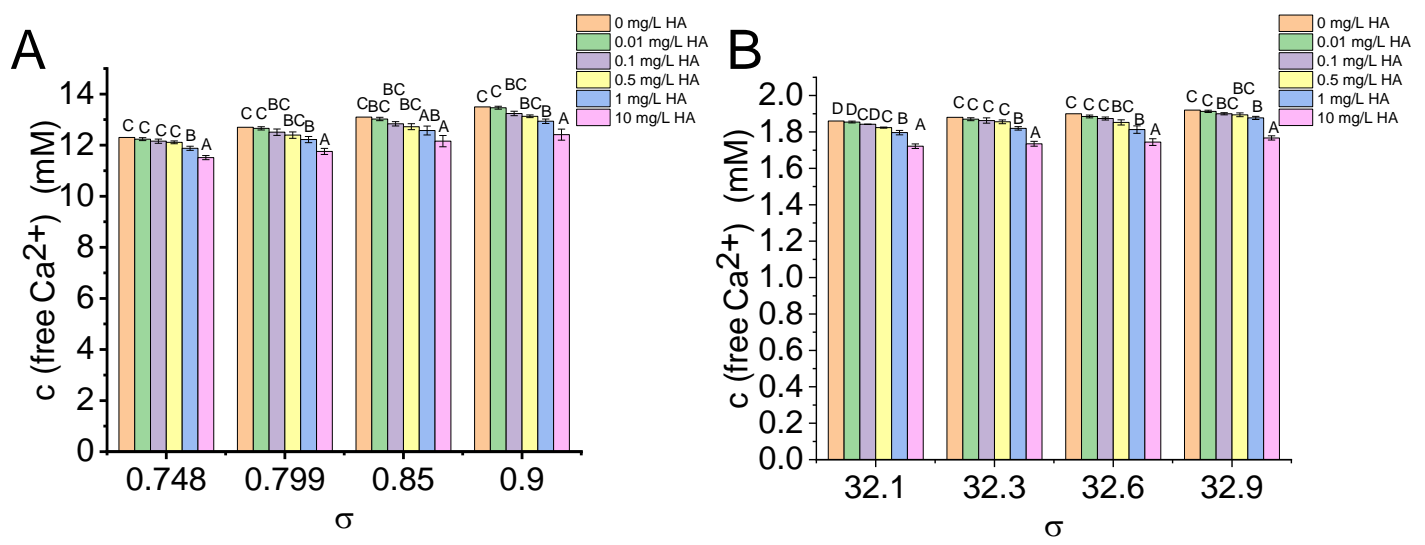

Figure S20. ISE measurements of free $\mathrm{Ca}^{2+}$ concentrations in different solutions 
supersaturated with respect to (A) DCPD ( $\mathrm{pH} 5.6, I S=0.15 \mathrm{M}, 25^{\circ} \mathrm{C}$ ) or (B) HAP $\left(\mathrm{pH} 8.0, I S=0.15 \mathrm{M}, 25^{\circ} \mathrm{C}\right.$ ) in the absence and presence of different concentrations of HA (0.01-10 mg/L).

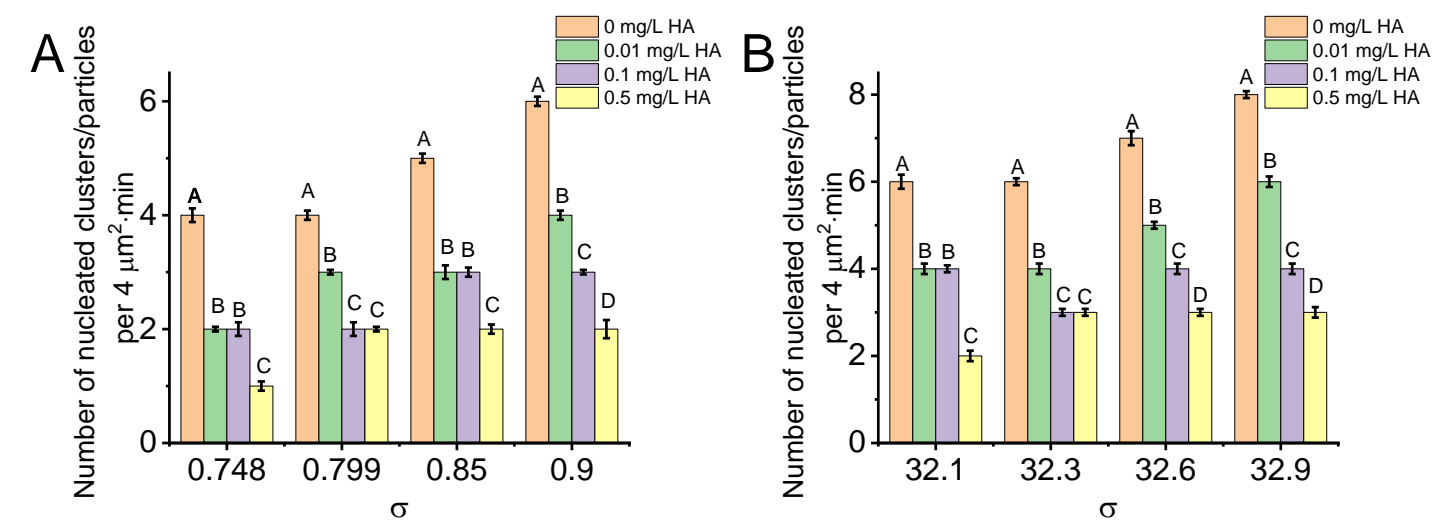

Figure S21. Nucleation rates in different solutions supersaturated with respect to (A) DCPD (pH 5.6, IS $=0.15 \mathrm{M}, 25{ }^{\circ} \mathrm{C}$ ) or (B) HAP (pH 8.0, IS $=0.15 \mathrm{M}, 25{ }^{\circ} \mathrm{C}$ ) in the absence and presence of different concentration of HA (0.01-0.5 mg/L). Uppercase letters indicate a significant difference at $\mathrm{P}<0.01$ which was analyzed by SPSS software.
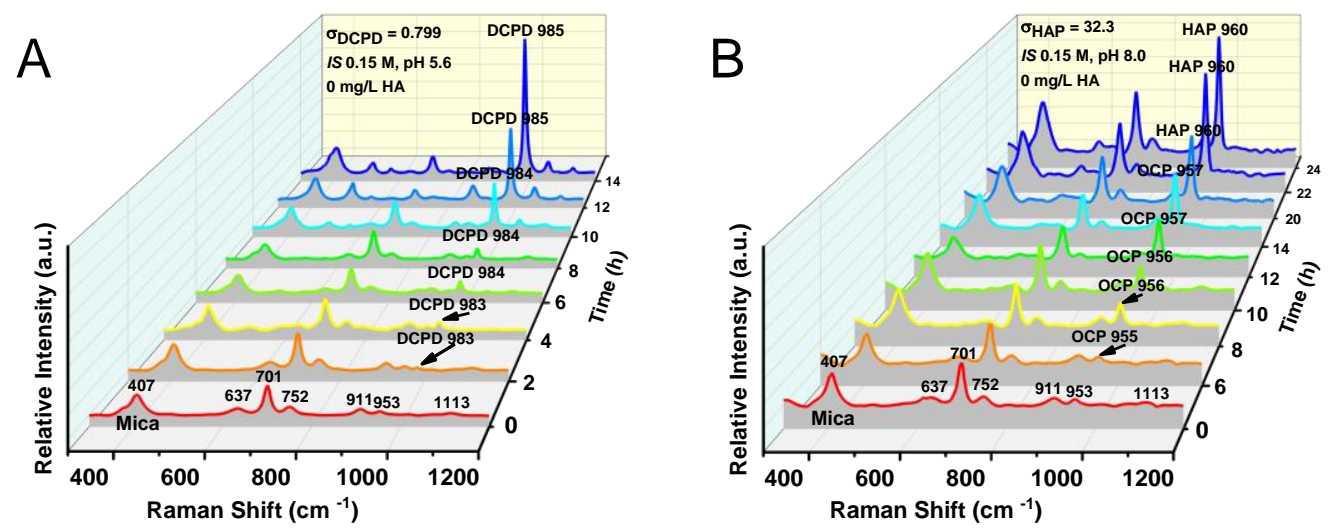

Figure S22. Representative real-time Raman spectra of the phase evolution of nucleated particles on mica in (A) supersaturated DCPD $\left(\sigma_{\mathrm{DCPD}}=0.799, I S=0.15 \mathrm{M}\right.$, $\left.\mathrm{pH} 5.6,25^{\circ} \mathrm{C}\right)$ or $(\mathrm{B}) \mathrm{HAP}\left(\sigma_{\mathrm{HAP}}=32.3, I S=0.15 \mathrm{M}, \mathrm{pH} 8.0,25^{\circ} \mathrm{C}\right)$ solutions in the absence of HA. Arrows in (A) and (B) show the initial occurrence of the peak at 983 $\mathrm{cm}^{-1}$ and $955 \mathrm{~cm}^{-1}$ after about $2 \mathrm{~h}$ and $6 \mathrm{~h}$ of reactions, respectively. 

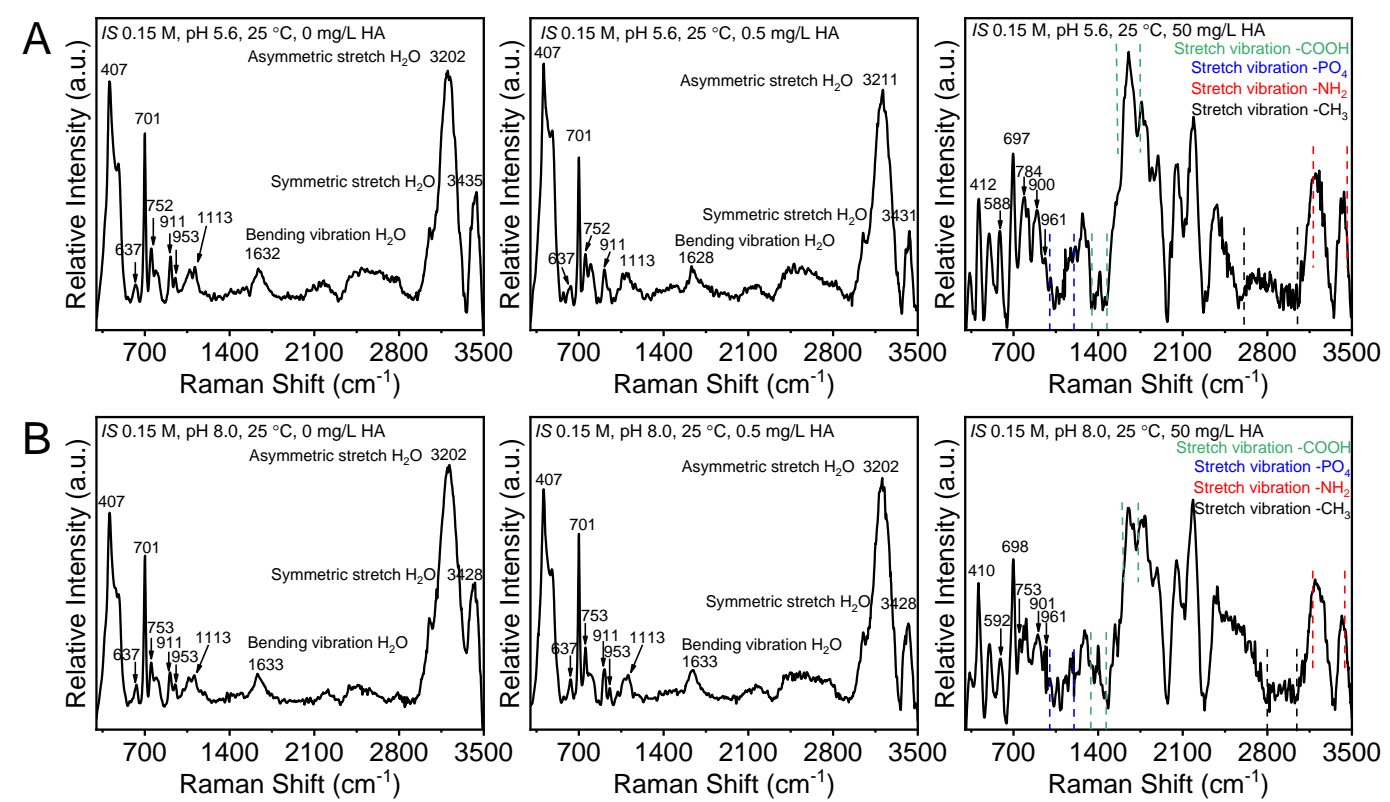

Figure S23. Raman spectra of mica in solutions in the absence and presence of HA at (A) $\mathrm{pH} 5.6$ or (B) 8.0 showing that $\mathrm{HA}$ characteristic bands (for functional groups $-\mathrm{COOH},-\mathrm{PO}_{4},-\mathrm{NH}_{2}$ and $-\mathrm{CH}_{3}$ ) occur only at $[\mathrm{HA}] \geq 50 \mathrm{mg} / \mathrm{L}$. Note that 407,637 , $701,752,911,953$ and $1113 \mathrm{~cm}^{-1}$ are characteristic vibrations of mica.

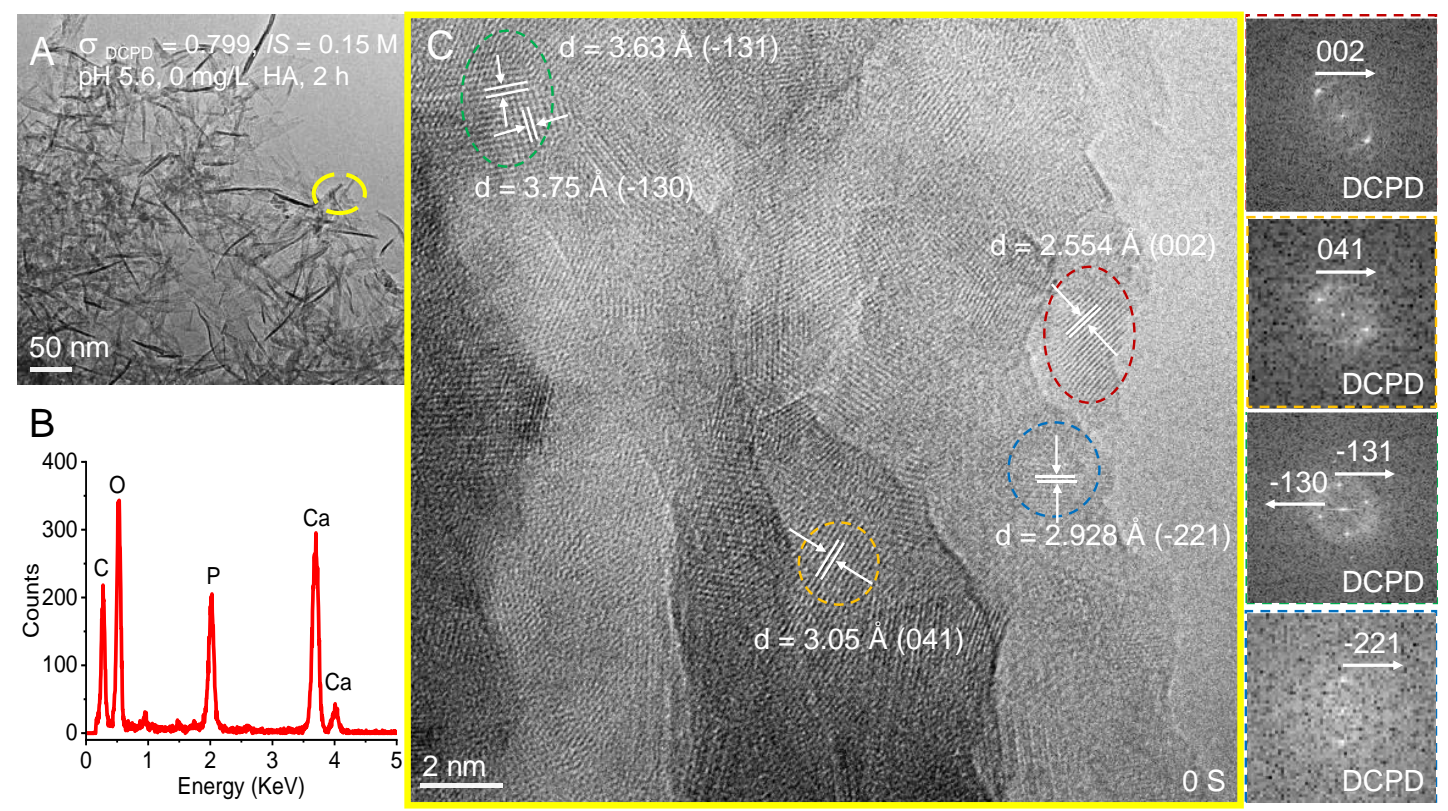

Figure S24. (A) TEM image showing precipitates isolated from DCPD supersaturated $\left(\sigma_{\text {DCPD }}=0.799, I S=0.15 \mathrm{M}, \mathrm{pH} 5.6,25^{\circ} \mathrm{C}\right)$ solutions in the absence of HA. (B) EDX spectrum demonstrating that the particles consist of $\mathrm{Ca}, \mathrm{P}, \mathrm{O}$ and $\mathrm{C}(\mathrm{C}$ is from supportive carbon film on $\mathrm{Cu}$ grids). (C) HRTEM images taken from a dotted yellow circle in (A) showing that most analyzed areas exhibited DCPD nanocrystallites with different faces, identified by the fast Fourier transform (FFT) diffraction patterns taken from four colored circles in $(\mathrm{C})$. 

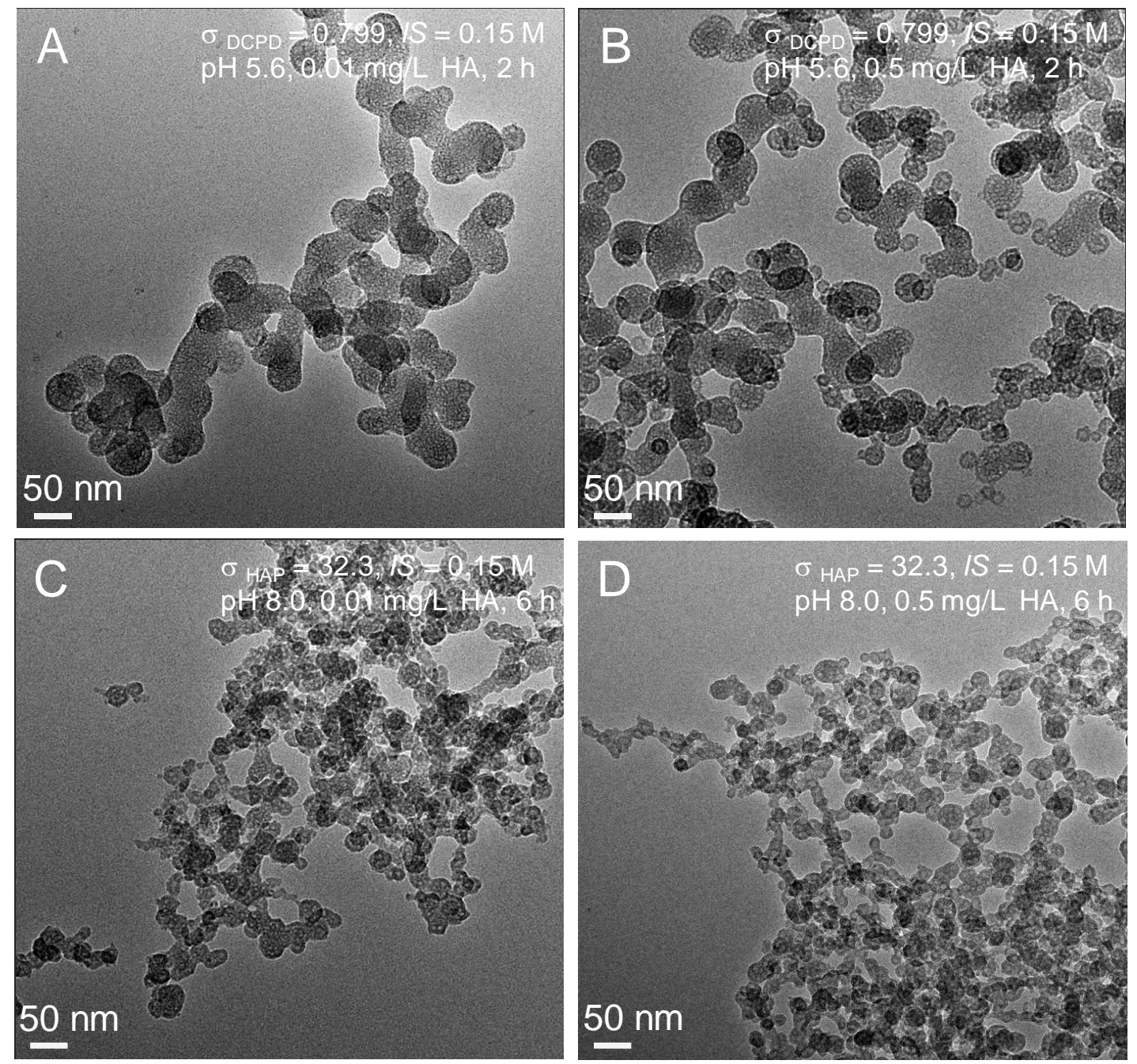

Figure S25. TEM images showing the spherical precipitated particles isolated from $(\mathrm{A}, \mathrm{B})$ DCPD supersaturated $\left(\sigma_{\mathrm{DCPD}}=0.799, I S=0.15 \mathrm{M}\right.$, $\left.\mathrm{pH} 5.6,25^{\circ} \mathrm{C}\right)$ solutions or $(\mathrm{C}, \mathrm{D}) \mathrm{HAP}$ supersaturated $\left(\sigma_{\mathrm{HAP}}=32.3, I S=0.15 \mathrm{M}, \mathrm{pH} 8.0,25^{\circ} \mathrm{C}\right)$ solutions in the presence of 0.01 or $0.5 \mathrm{mg} / \mathrm{L} \mathrm{HA}$.

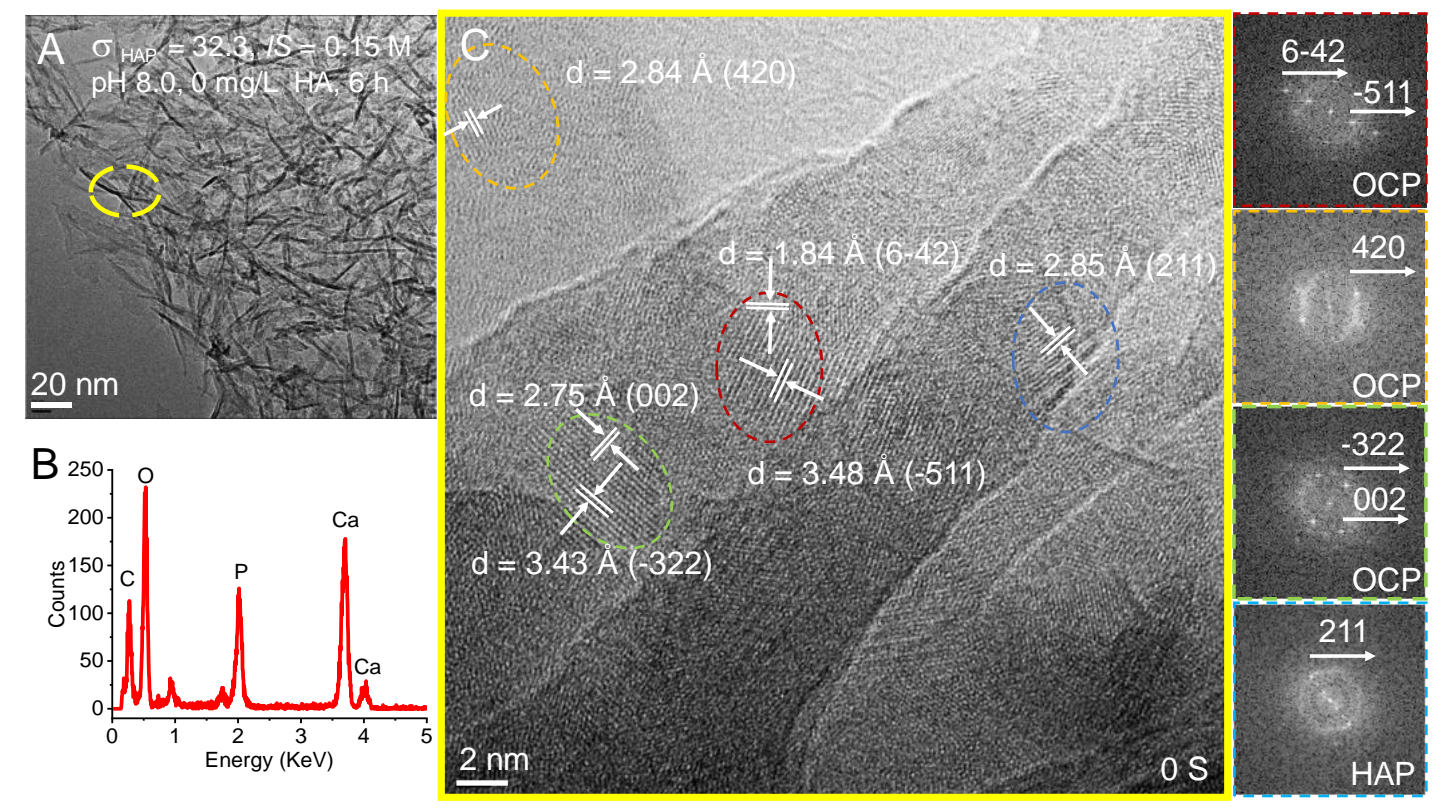


Figure S26. (A) TEM image showing the precipitates isolated from HAP supersaturated $\left(\sigma_{\mathrm{HAP}}=32.3, I S=0.15 \mathrm{M}, \mathrm{pH} 8.0,25^{\circ} \mathrm{C}\right)$ solutions in the absence of HA. (B) EDX spectrum demonstrating that the particles consist of $\mathrm{Ca}, \mathrm{P}, \mathrm{O}$ and $\mathrm{C}(\mathrm{C}$ is from supportive carbon film on $\mathrm{Cu}$ grids). (C) HRTEM images taken from a dotted yellow circle in (A) showing that most analyzed areas exhibited crystalline phases, including OCP (yellow, red and green circles) and HAP (blue circle) and identified by the fast Fourier transform (FFT) diffraction patterns taken from four colored circles in C.
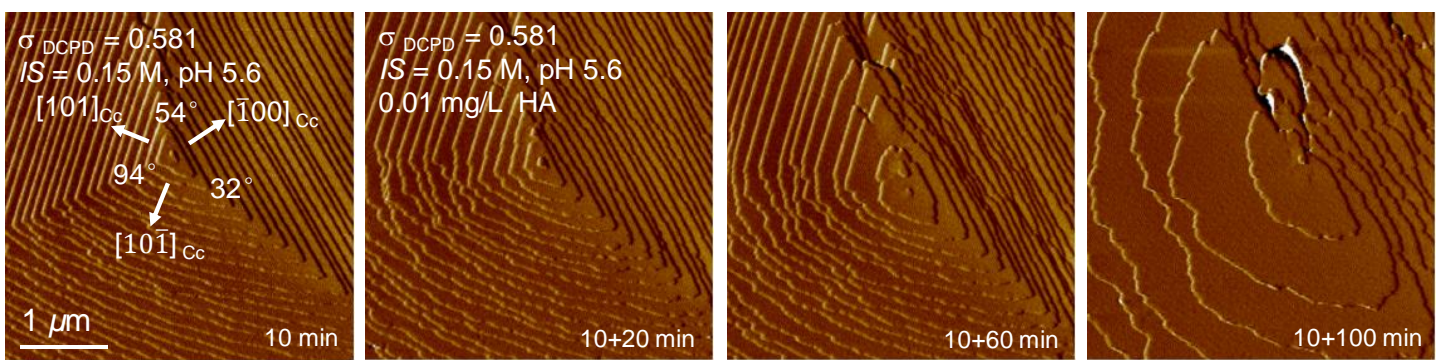

Figure S27. Time sequence (AFM deflection images) of a growing triangular spiral with 32-54-94 degrees on a DCPD (010) face in a supersaturated solution $\left(\sigma_{\mathrm{DCPD}}=\right.$ $0.581, I S=0.15 \mathrm{M}, \mathrm{pH} 5.6,25^{\circ} \mathrm{C}$ ) before and after addition of $0.01 \mathrm{mg} / \mathrm{L} \mathrm{HA}$. After 100 min of addition of HA, the step edges along three movement directions of the $[101]_{\mathrm{Cc}},[10 \overline{1}]_{\mathrm{Cc}}$, and $[\overline{100}]_{\mathrm{Cc}}$ were pinned, roughened, and eventually became undefined.
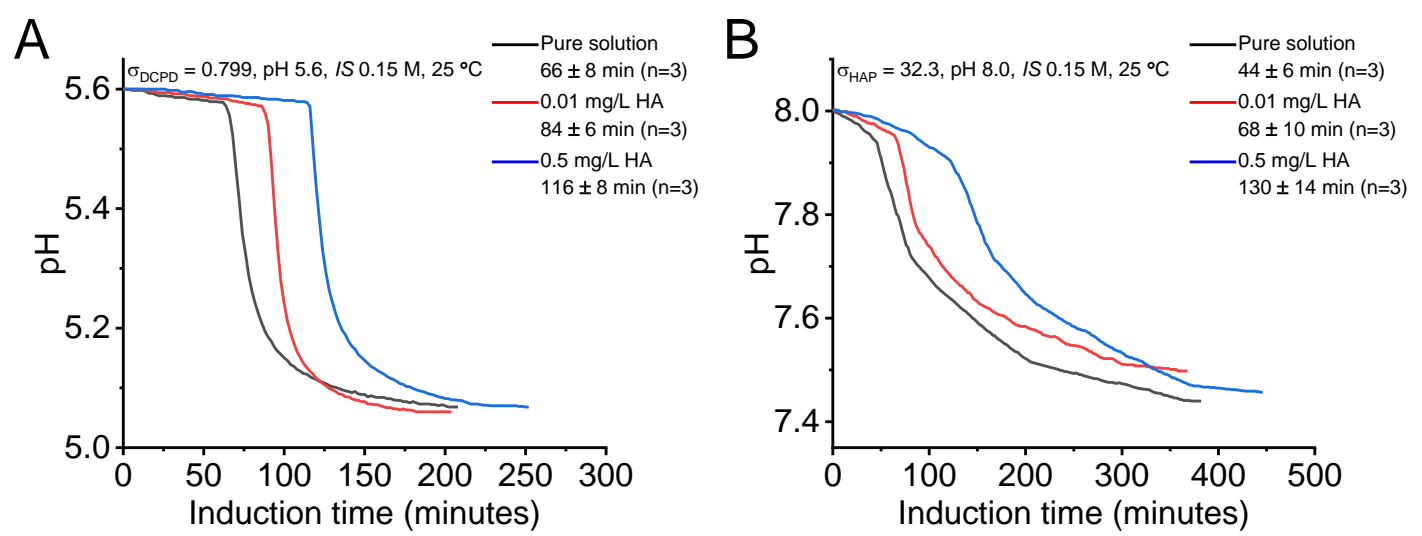

Figure S28. $\mathrm{pH}$ curves versus time for (A) DCPD and (B) HAP crystallization in the absence and presence of $\mathrm{HA}$ at 0.01 and $0.5 \mathrm{mg} / \mathrm{L}$, showing that HA dramatically inhibits the nucleation by prolonging the induction time in a concentration of HA-dependent manner. 

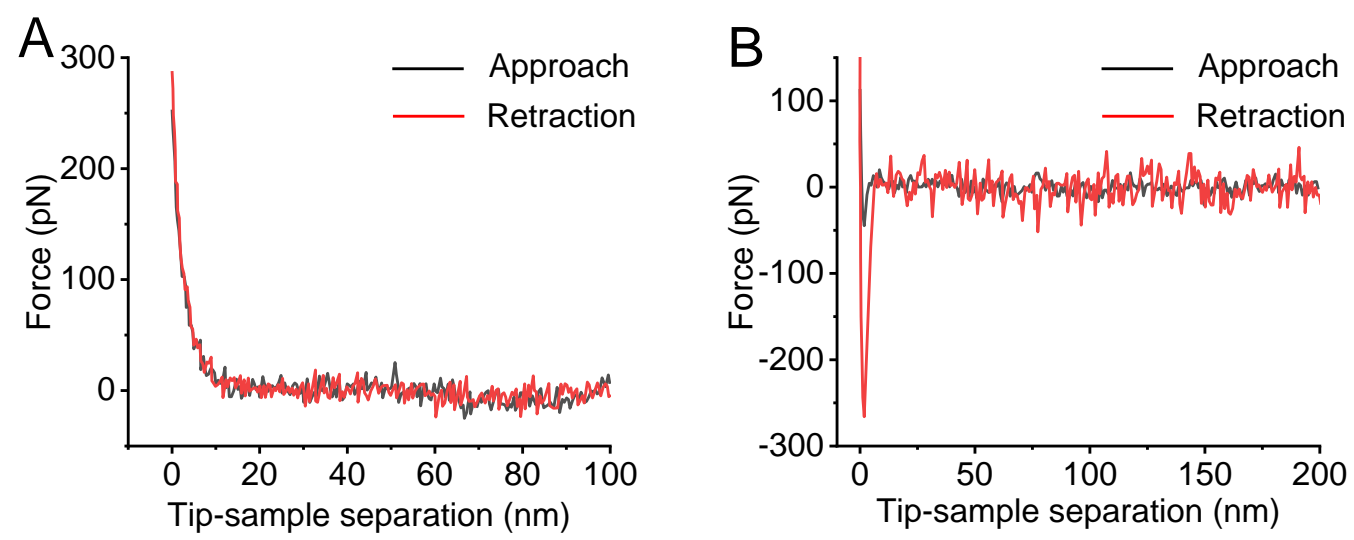

Figure S29. (A) Representative force-distance curves between the Au-coated tip with mica. (B) Representative force-distance curves between the functional group ( $\left.\mathrm{COO}^{-}\right)$ on Au-coated tip with mica, showing typical force-distance curves between the modified tip and the mica compared with non-force peaks on Au-coated tip.

\section{References}

1. Wang, L. J.; Nancollas, G. H. Calcium orthophosphates: crystallization and dissolution. Chem. Rev. 2008, 108, 4628-4669.

2. Kumar, R. R.; Wang, M. Biomimetic deposition of hydroxyapatite on brushite single crystals grown by the gel technique. Mater. Lett. 2001, 49, 15-19.

3. Dorozhkin, S. V. Amorphous calcium (ortho)phosphates. Acta. Biomater. 2010, 6, 4457-4475.

4. Combes, C.; Rey, C. Amorphous calcium phosphates: synthesis, properties and uses in biomaterials. Acta. Biomater. 2010, 6, 3362-3378.

5. Somrani, S.; Banu, M.; Jemal, M.; Rey, C. Physico-chemical and thermochemical studies of the hydrolytic conversion of amorphous tricalcium phosphate into apatite. J. Solid State Chem. 2005, 178, 1337-1348.

6. Iijima, M.; Onuma, K. Roles of fluoride on octacalcium phosphate and apatite formation on amorphous calcium phosphate substrate. Cryst. Growth Des. 2018, $18,2279-2288$.

7. Onuma, K.; Iijima, M. Artificial enamel induced by phase transformation of amorphous nanoparticles. Sci. Rep. 2017, DOI:10.1038/s41598-017-02949-w.

8. Newcomb, C. J.; Qafoku, N. P.; Grate, J. W.; Bailey, V. L.; De Yoreo, J. J. Developing a molecular picture of soil organic matter-mineral interactions by quantifying organo-mineral binding. Nat. Commun. 2017, DOI: 10.1038/s41467-017-00407-9.

9. Burnham, N. A.; Chen, X.; Hodges, C. S.; Matei, G. A.; Thoreson, E. J.; Roberts, C. J.; Davies, M. C.; Tendler, S. J. B. Comparison of calibration methods for atomic-force microscopy cantilevers. Nanotechnology 2003, 14, 1-6.

10. Friddle, R. W.; Noy, A.; De Yoreo, J. J. Interpreting the widespread nonlinear force spectra of intermolecular bonds. Proc. Natl. Acad. Sci. U. S. A. 2012, 109, 13573-13578. 
11. Mckeown, D. A.; Bell, M. I.; Etz, E. S. Vibrational analysis of the dioctahedral mica: 2M1 muscovite. Am. Mineral. 1999, 84, 1041-1048.

12. Sauer, G. R.; Zunic, W. B.; Durig, J. R.; Wuthier, R. E. Fourier transform raman spectroscopy of synthetic and biological calcium phosphates. Calcified Tissue Int. 1994, 54, 414-420.

13. Crane, N. J.; Popescu, V.; Morris, M. D.; Steenhuis, P.; Ignelzi, M. A. Raman spectroscopic evidence for octacalcium phosphate and other transient mineral species deposited during intramembranous mineralization. Bone 2006, 39, 434-442.

14. Hay, M. B.; Myneni, S. C. B. Structural environments of carboxyl groups in natural organic molecules from terrestrial systems. part 1: infrared spectroscopy. Geochim. Cosmochim. Acta 2007, 71, 3518-3532.

15. Lamba, O. P.; Borchman, D.; Sinha, S. K.; Lal, S.; Yappert, M. C.; Lou, M. F. Structure and molecular conformation of anhydrous and of aqueous sphingomyelin bilayers determined by infrared and raman spectroscopy. J. Mol. Struct. 1991, 248, 1-24.

16. Stewart; James, E. Vibrational spectra of primary and secondary aliphatic amines. J. Chem. Phys. 1959, DOI.org/10.1063/1.1730168.

17. Szasz, G. J.; Sheppard, N.; Rank, D. H. Spectroscopic studies of rotational isomerism. i. liquid n-butane and the assignment of the normal modes of vibration. J. Chem. Phys. 1948, DOI.org/10.1063/1.1746978.

18. Durocher, G.; Williams, D. F. Polarized singlet-triplet absorption spectra of normal and deuterated anthracene crystals. J. Chem. Phys. 1969, DOI.org/10.1063/1.1671963.

19. Slovetskii, V. I. IR spectra of nitro compounds. Bull. Acad. Sci. Ussr Div. Chem. Sci. 1970, 19, 2086-2091.

20. Saier, E. L.; Cousins, L. R.; Basila, M. R. Band shape of the OH stretching vibration in aliphatic alcohols. evidence for the occurrence of an intramolecular interaction. J. Chem. Phys. 1964, DOI.org/10.1063/1.1725645.

21. Moore, C. B.; Pimentel, G. C. Infrared spectrum and vibrational potential function of ketene and the deuterated ketenes. J. Chem. Phys. 1963, DOI.org/10.1063/1.1733608.

22. Singh, R. K.; Asthana, B. P.; Singh, P. R.; Chakraborty, T.; Verma, A. L. Raman study of the vibrational relaxation of the $v(\mathrm{c} \equiv \mathrm{n})$ stretching mode of acrylonitrile in binary liquid mixtures with hydrogen donor solvents. J. Raman Spectrosc. 1998, 29, 561-566.

23. Kataeva, L. M.; Shagidullin, R. R.; Rydvanskii, Y. V.; Fazliev, D. F.; Kataev, E. G. Frequencies and intensities of the $v \mathrm{c} \equiv \mathrm{c}$ lines in the Raman spectra of acetylenic thio-, seleno-, and telluroethers. J. Appl. Spectrosc. 1979, 30, 526-528.

24. Burikov, S. A.; Dolenko, T. A.; Karpov, D. M. The contribution of fermi resonance to the formation of the Raman valence band of water. Opt. Spectrosc. 2010, 109, 272-278. 